\title{
Beneficial effects of dried pomegranate juice concentrated powder on ultraviolet B-induced skin photoaging in hairless mice
}

\author{
SU-JIN KANG ${ }^{1,2^{*}}$, BEOM-RAK CHOI $^{3 *}$, SEUNG-HEE KIM $^{3}$, HAE-YEON YI $^{3}$, HYE-RIM PARK $^{3}$, \\ CHANG-HYUN SONG ${ }^{1,4}$, SAE-KWANG KU ${ }^{1,4}$ and YOUNG-JOON LEE ${ }^{1,2}$ \\ ${ }^{1}$ The Medical Research Center for Globalization of Herbal Medicine; ${ }^{2}$ Department of Preventive Medicine, College of \\ Korean Medicine, Daegu Haany University, Gyeongsan, Gyeongsangbuk-do 38610; ${ }^{3}$ Research Institute, Health-Love Co., \\ Ltd., Anyang, Gyeonggi-do 13946; ${ }^{4}$ Department of Histology and Anatomy, College of Korean Medicine, \\ Daegu Haany University, Gyeongsan, Gyeongsangbuk-do 38610, Republic of Korea
}

Received February 8, 2017; Accepted April 28, 2017

DOI: 10.3892/etm.2017.4626

\begin{abstract}
The present study investigated the anti-aging effects of pomegranate juice concentrated powder (PCP) in hairless mice following 15 weeks of UVB irradiation (three times a week; $0.18 \mathrm{~J} / \mathrm{cm}^{2}$ ). Skin moisturizing effects were evaluated through skin water, collagen type I and hyaluronan contents, as well as collagen type I and hyaluronan synthesis-related transcript levels. Wrinkle formation and edema scores (skin weights) were also assessed, along with skin matrix metalloproteinase (MMP)-1, MMP-9 and MMP-13 transcript levels.
\end{abstract}

Correspondence to: Professor Young-Joon Lee, Department of Preventive Medicine, College of Korean Medicine, Daegu Haany University, 1 Haanydae-ro, Gyeongsan, Gyeongsangbuk-do 38610, Republic of Korea

E-mail: gksxntk@dhu.ac.kr

Professor Sae-Kwang Ku, Department of Histology and Anatomy, College of Korean Medicine, Daegu Haany University, 1 Haanydae-ro, Gyeongsan, Gyeongsangbuk-do 38610, Republic of Korea

E-mail: gucci200@hanmail.net

*Contributed equally

Abbreviations: 4-HNE, 4-hydroxynonenal; ABC, avidin-biotin complex; COL1, collagen, type I; COL1A1, COL1 $\alpha$ 1; COL1A2, COL1 $\propto$ 2; ECM, extracellular matrix; ELISA, enzyme linked immunosorbent assay; GSH, glutathione; Has, hyaluronic acid synthase; IL, interleukin; MDA, malondialdehyde; MMP, matrix metalloproteinase; MPO, myeloperoxidase; MT, Masson's trichrome; NBT, nitroblue tetrazolium; Nox2, Gp91phox subunit of the phagocyte NADPH oxidase; NT, nitrotyrosine; PARP, cleaved poly(ADP-ribose) polymerase; PCP, dried pomegranate juice concentrated powder; PCS, pomegranate juice concentrated solution; ROS, reactive oxygen species; RT-qPCR, reverse transcription-quantitative polymerase chain reaction; UV, ultraviolet

Key words: dried pomegranate juice concentrated powder, photoaging, ultraviolet B, skin moisturizing effect, apoptosis, antioxidant effect, anti-inflammatory effect
To determine the anti-inflammatory effects of PCP, myeloperoxidase (MPO) activity, interleukin (IL)-1 $\beta$ and IL-10 contents were observed. Caspase- 3 and cleaved poly(ADP-ribose) polymerase (PARP) were used as an apoptotic index in epidermal keratinocytes. To determine the anti-oxidative effects of PCP, nitrotyrosine and 4-hydroxynonenal immunoreactive cells were detected and glutathione (GSH) content, malondialdehyde levels, superoxide anion production, Nox 2 , and GSH reductase mRNA expression were all measured. The results indicated that skin wrinkles induced by photoaging were significantly reduced by PCP, whereas skin water contents, collagen type I and hyaluronan contents all increased. Furthermore, IL-1 $\beta$ levels in the PCP-treated groups were lower than those in the UVB-exposed control group. UVB-induced GSH depletion was also inhibited by PCP. Taken together, the results of the current study suggest that PCP has favorable protective effects against UVB-induced photoaging through anti-apoptotic effects, MMP activity inhibition and ECM (COL1 and hyaluronan) synthesis-related moisturizing, anti-inflammatory and anti-oxidative effects.

\section{Introduction}

Prolonged exposure of human skin to ultraviolet B (UVB) radiation (290-320 $\mathrm{nm}$ ) induces clinical and histological alterations due to the onset of simultaneous destruction and repair (1). Environmental factors, such as solar light, may lead to extrinsic aging, which occurs due to dyspigmentation, telangiectasia and collagen degradation $(2,3)$. The pathogenesis of skin photoaging induced by UVB involves reactive oxygen species (ROS)-mediated inflammation (4-6), keratinocyte apoptosis $(7,8)$ and the degradation of matrix macromolecules by matrix metalloproteinases (MMPs) (9). Consequently, wrinkle formation, epidermal thickening (10), extracellular matrix (ECM) degradation-related water loss and skin dryness (11) all increase. Thus, it is important to reduce UVB-induced skin aging, as the maintenance of skin health against UVB exposure is directly associated with whole body health $(10,12)$.

ROS may be generated by UV irradiation and damage cellular lipids, proteins and DNA, resulting in the alteration 
and destruction of skin structures. This may result in the failure of the skin to function normally (13). UVB-induced ROS overproduction leads to an imbalance between ROS and antioxidant enzymes, as well as a reduction in glutathione (GSH) levels $(14,15)$. Furthermore, UVB exposure triggers the release of numerous cytokines that participate in the onset of cutaneous inflammation $(16,17)$. These molecules serve an important role in edema, which occurs as a result of vasodilation, the opening of interendothelial junctions and the separation of endothelial cells, which increases microvascular protein and fluid leakage into the interstitium (18).

It has been suggested that there is a link between oxidative stress and levels of inflammatory cytokines. For example, the potent pro-inflammatory cytokine interleukin (IL)- $1 \beta$ may trigger nicotinamide adenine dinucleotide phosphate (NADPH) oxidase, which can produce free radical including superoxide anions. In turn, superoxide anion-induced nuclear factor- $\kappa \mathrm{B}(\mathrm{NF}-\kappa \mathrm{B})$ serves an important in the production of cytokines (19). In this context, antioxidants from natural sources may provide novel possibilities for inhibiting UVB-induced oxidative stress-mediated events (4).

Pomegranates contain fibre, pectin, sugar and several tannins (20), as well as flavonoids and anthocyanidins in their seed oil and juice (21). Kim et al (22) demonstrated that pomegranates possess chemopreventative and adjuvant therapeutic effects against human breast cancer cells. Due to such biological activities, the consumption of pomegranate-containing foods is increasing (21).

In a previous study by our group, it was determined that pomegranate juice concentrated solution (PCS) exhibited protective effects against UVB-induced photoaging in in vivo and in vitro model systems $(23,24)$. Additionally, dried pomegranate juice concentrated powder $(\mathrm{PCP})$ significantly inhibited melanin formation in B16F10 melanocytes (25). Thus, it is hypothesized that PCP may exert protective effects against photoaging.

The aim of the present study was to examine the anti-aging effect of PCP in UVB-induced skin photoaging. An oral dose of $2 \mathrm{ml} / \mathrm{kg}$ PCS was used as a reference, as it has been demonstrated that PCS exerts protective effects against UVB-induced skin photoaging $(23,24)$.

\section{Materials and methods}

Animals and husbandry. A total of 66 6-week healthy female SKH-1 hairless mice were obtained from Orient Bio, Inc. (Seongnam, Korea). The experimental groups were divided into the following 6 groups ( 8 mice per group), based on the body weights 7 days after acclimatization $(23.32 \pm 0.93 \mathrm{~g}$, range, 21.4-24.8 g/head): Intact vehicle control-unexposed (mice received vehicle-control); UVB control-UVB exposed (mice received vehicle control and UVB exposure); PCS-UVB exposed (mice received PCS $2 \mathrm{ml} / \mathrm{kg}$ and UVB exposure); PCP $100 \mathrm{mg} / \mathrm{kg}$-UVB exposed (mice received PCP $100 \mathrm{mg} / \mathrm{kg}$ and UVB exposure); PCP $200 \mathrm{mg} / \mathrm{kg}$-UVB exposed (mice received PCP $200 \mathrm{mg} / \mathrm{kg}$ and UVB exposure); and PCP $400 \mathrm{mg} / \mathrm{kg}-\mathrm{UVB}$ exposed (mice received PCP $400 \mathrm{mg} / \mathrm{kg}$ and UVB exposure). During acclimatization and experimental periods, animals were kept at a temperature of $20-25^{\circ} \mathrm{C}$, a humidity of $50-55 \%$ and were exposed to a 12-h light/dark cycle in polycarbonate cages (4 rats per cage). Mice had ad libitum access to standard rodent chow (Samyang Corporation, Seoul, Korea) and tap water. All procedures involving laboratory animals followed the national regulations for the usage and welfare of laboratory animals (26). The protocol of the current study was approved by the Institutional Animal Care and Use Committee of Daegu Haany University (Gyeongsan, Korea) prior to the experiment (approval no. DHU2015-066).

UVB irradiation. UVB irradiation was performed three times a week for 15 weeks at $0.18 \mathrm{~J} / \mathrm{cm}^{2}$ following the protocol of a previous study (27). Peak emission was measured at $312 \mathrm{~nm}$ using a UV Crosslinker system (Hoefer Scientific Instruments, San Francisco, CA, USA). Unexposed intact control mice were also exposed to the non-emitting Crosslinker system for the same duration as the UVB-exposed hairless mice.

Preparation and administration of test materials. PCS was purchased from ASYA Meyve Suyu ve Gida San. A.Ş. (Ankara, Turkey). PCS contained $2.31 \mathrm{mg} / \mathrm{g}$ ellagic acid as an active ingredient and consisted of $58.86 \%$ carbohydrate, $1.21 \%$ total protein, $0.49 \%$ fat, $27.97 \%$ water, $1.47 \%$ ash and $10 \%$ unidentified ingredients, as well as $28.03 \mathrm{mg} / 100 \mathrm{~g}$ sodium at proximate analysis. Health-Love Co. (Anyang, Korea) purchased raw materials of PCS and PCP from ASYA Meyve Suyu ve Gida San. A.Ş. and supplied the processed products after ingredients analysis and quality control. PCP (ASYA Meyve Suyu ve Gida San. A.Ş.) containing $1.15 \mathrm{mg} / \mathrm{g}$ ellagic acid and $0.22 \mathrm{mg} / \mathrm{g}$ punicalagin as active ingredients. All test materials were stored at $4^{\circ} \mathrm{C}$ in a refrigerator to protect from light and moisture. A PCP dose of $200 \mathrm{mg} / \mathrm{kg}$ was selected based on the in vitro skin whitening effect (25) and the clinical dose in humans [mouse dosage was $200 \mathrm{mg} / \mathrm{kg}, \sim 12$-fold the human dosage; $(1,000 \mathrm{mg} / 60 \mathrm{~kg}) \times 12=200 \mathrm{mg} / \mathrm{kg}]$ and doses of 400 and $100 \mathrm{mg} / \mathrm{kg}$ were selected as the highest and lowest doses, respectively, using a ratio of 2. Similarly, a PCS dose of $2 \mathrm{ml} / \mathrm{kg}$ was selected based on a previous efficacy study investigating UVB-induced photoaging $(23,24)$ and also based on the clinical dose in humans [mouse dosage was $\sim 12$-fold the human dosage; $(10 \mathrm{ml} / 60 \mathrm{~kg}) \times 12=2 \mathrm{ml} / \mathrm{kg}]$. PCP was dissolved in distilled water to obtain concentrations of 40,20 and $10 \mathrm{mg} / \mathrm{ml}$, and a volume of $10 \mathrm{ml} / \mathrm{kg}$ was orally administered using a gastric gavage attached syringe, resulting in administration of 400,200 and $100 \mathrm{mg} / \mathrm{kg}$, respectively. PCS was diluted in distilled water in 1:4 ratios $(\mathrm{v} / \mathrm{v})$ and a volume of $10 \mathrm{ml} / \mathrm{kg}$ was orally administered, resulting in administration of $2 \mathrm{ml} / \mathrm{kg}$ of body weight, respectively. The different doses of PCP 100, 200 and $400 \mathrm{mg} / \mathrm{kg}$, and PCS $2 \mathrm{ml} / \mathrm{kg}$ were administered to 8 mice in each PCP group once per day for 15 weeks beginning $1 \mathrm{~h}$ after initial UVB exposure. Equal volumes of vehicle (distilled water) were orally administered to all mice in the intact and UVB control groups.

Generation of replicas and image analysis. After obtaining photos of the dorsal skin around the gluteal region, animals were sacrificed by over exdanguination through vena cava under anesthesia (3\% isoflurane; Hana Pharm Co., Ltd., Hwasung, Korea) and dissected. Replicas of mouse dorsal skin were obtained using the Repliflo Cartridge kit (CuDerm Corp., Dallas, TX, USA). Impression replicas were set on a 
horizontal sample stand and wrinkle shadows were produced by illumination with a fixed-intensity light at a $40^{\circ}$ angle. Black and white images were recorded using a CCD camera and analyzed using the Skin-Visiometer ${ }^{\circledR}$ VL650 (Courage and Khazaka, Cologne, Germany). To analyze skin wrinkles, the average length and average depth of wrinkles were measured using a previously described method (10).

Edema evaluation. To assess the effects of PCP and PCS on UVB-induced skin edema, changes in dorsal skin weight were examined using a previously established method (4). Dorsal skin was removed, a 6-mm diameter was delimited with the aid of a punch and this area was then weighed. Changes were measured following 15 weeks of continuous oral administration of PCP, PCS or distilled water. The results were calculated by comparing the weight of the skin between groups and expressed as g/6-mm diameter of dorsal skin.

Skin water content measurement. The day after the final administration of test substances, $6 \mathrm{~mm}$-diameter of dorsal back skin samples were removed and skin water contents (\%) were measured using an automated moisture analyzer balance (MB23; Ohaus Corporation, Parsippany, NJ, USA), according to a previous study (28).

Detection of collagen type I (COL1) contents in skin tissue. COL1 contents were measured following a previously established method (29). Briefly, parts of the dorsal back skin tissues were separated and tissue homogenates were prepared using a homogenization system (Model TacoTMPre; GeneResearch Biotechnology Corp., Taichung, Taiwan), an ultrasonic cell disruptor (Model KS-750; Madell Technology Corp., Ontario, CA, USA) and radioimmunoprecipitation assay buffer (Sigma-Aldrich; Merck KGaA, Darmstadt, Germany). Following the seperation of supernatants by centrifugation at $21,000 \times \mathrm{g}$ for $10 \mathrm{~min}$ at $4^{\circ} \mathrm{C}$, the amount of pro-collagen type I was measured using a pro-collagen type I C peptide assay kit (Takara Bio, Inc., Otsu, Japan) according to the manufacturer's protocol and absorbance was measured at $450 \mathrm{~nm}$ using a microplate reader (Tecan Group Ltd., Männedorf, Switzerland).

Hyaluronan contents in skin tissue. Hyaluronan contents in the supernatant prepared from skin tissue homogenates were measured using a previously described method (30). Briefly, the fat in the sampled dorsal back skins was removed using acetone. Samples were then dried, weighed and boiled for $20 \mathrm{~min}$ in $50 \mathrm{mM}$ Tris/HCl (pH 7.8) buffer. Subsequently, samples underwent proteolytic digestion with $1 \% \mathrm{w} / \mathrm{v}$ actinase E (Sigma-Aldrich; Merck KGaA) for 1 week at $40^{\circ} \mathrm{C}$. Trichloroacetic acid (Sigma-Aldrich; Merck KGaA) was added to the samples at a final concentration of $10 \% \mathrm{w} / \mathrm{v}$ to induce deproteinization prior to centrifugation at $4,000 \mathrm{xg}$ at $4^{\circ} \mathrm{C}$ for $20 \mathrm{~min}$. The supernatants were subsequently neutralized using $10 \mathrm{~N} \mathrm{NaOH}$. Hyaluronan levels were measured using the QnE hyaluronic acid enzyme-linked immunosorbent assay (ELISA) kit (cat no. BTP-96200; Biotech Trading Partners, Encinitas, CA, USA), according to the manufacturer's protocol. Color intensity was measured at $450 \mathrm{~nm}$ using a spectrophotometer (OPTIZEN POP, Mecasys, Daejeon, Korea).
Measurement of myeloperoxidase (MPO) activity. MPO activity was measured using the MPO kinetic-colorimetric assay, according to a previously described method (4). A total of $50 \mathrm{mM} \mathrm{K}_{2} \mathrm{HPO}_{4}$ buffer (pH 6.0; Sigma-Aldrich; Merck KGaA) containing $0.5 \%$ hexadecyltrimethylammonium bromide (Gibco; Thermo Fisher Scientific, Inc., Waltham, MA, USA) was used to collect and homogenize skin samples in an ice bath for $15 \mathrm{sec}$. Following centrifugation at $1,000 \mathrm{x} \mathrm{g}$ for $2 \mathrm{~min}$ at $4^{\circ} \mathrm{C}$, the supernatant was removed. A total of $30 \mu 1$ supernatant sample was mixed with $200 \mu \mathrm{l} 0.05 \mathrm{M} \mathrm{K}_{2} \mathrm{HPO}_{4}$ buffer (pH 6.0), containing $0.167 \mathrm{mg} / \mathrm{ml}$ o-dianisidine dihydrochloride (Sigma-Aldrich; Merck KGaA) and $0.05 \%$ hydrogen peroxide. After $5 \mathrm{~min}$, the absorbance of the samples was measured using a spectrophotometer at $450 \mathrm{~nm}$. The MPO activity of samples was compared with a standard curve of neutrophils and protein levels in the skin homogenates was measured using the Lowry method (31). The results are presented as MPO activity (number of total neutrophils/mg protein).

Detection of $I L-1 \beta$ and $I L-10$ in skin tissue. The dorsal back skin tissue from the area around gluteal region was collected. Collected tissue was homogenized and processed as described by Botelho et al (32). IL-10 and IL-1 $\beta$ concentrations were determined using the enzyme-linked immunosorbent assay (ELISA) kit (cat no. ab108870 for IL-10; cat no. ab100705 for IL-1 $\beta$; Abcam, Cambridge, UK), according to the manufacturer's instructions. Absorbance was measured at $490 \mathrm{~nm}$ using a microplate reader.

GSH assay. Following skin homogenization (1:3, w/w dilution) in $100 \mathrm{mM} \mathrm{NaH}{ }_{2} \mathrm{PO}_{4}$ (pH 8.0; Sigma-Aldrich; Merck $\mathrm{KGaA}$ ) containing $5 \mathrm{mM}$ EDTA, 30\% trichloroacetic acid (Sigma-Aldrich; Merck KGaA) was added to homogenates. Mixtures were then centrifuged twice (once at 1,940 x g for $6 \mathrm{~min}$ at $4^{\circ} \mathrm{C}$ and once at $485 \mathrm{x} \mathrm{g}$ for $10 \mathrm{~min}$ at $4^{\circ} \mathrm{C}$ ) and the fluorescence of the resulting supernatant was measured using a fluorescence spectrophotometer (RF-5301PC; Shimadzu Corporation, Tokyo, Japan). Supernatant (100 $\mu \mathrm{l})$ was mixed with $1 \mathrm{ml}$ buffer 1 and $100 \mu \mathrm{l}$ o-phthalaldehyde $(1 \mathrm{mg} / \mathrm{ml}$ in methanol; Sigma-Aldrich; Merck KGaA). After 15 min, the absorbance was measured at $420 \mathrm{~nm}$. A standard curve containing 0.0-75.0 $\mu \mathrm{M}$ GSH was prepared. Protein levels in the skin homogenates were measured using the Lowry method (31) and results are presented as $\mu \mathrm{M} \mathrm{GSH} / \mathrm{mg}$ protein. GSH levels were measured as reported previously (4).

Lipid peroxidation. Protein content of the homogenate (10 $\mathrm{mg} / \mathrm{ml}$ in $1.15 \% \mathrm{KCl}$ ) was measured using the Lowry method (31). To determine lipid peroxidation, levels of thiobarbituric acid reactive substances were measured following a previously described method (33). Briefly, 10\% trichloroacetic acid (Sigma-Aldrich; Merck KgaA) was mixed with the homogenate and this mixture was then centrifuged at $1,000 \mathrm{xg}$ at $4^{\circ} \mathrm{C}$ for $3 \mathrm{~min}$ to obtain protein-free samples. Thiobarbituric acid $(0.67 \%)$ was treated and the mixture was left to stand at $100^{\circ} \mathrm{C}$ for $15 \mathrm{~min}$. Levels of malondialdehyde (MDA), an intermediate product of lipoperoxidation, were measured by determining the difference between the absorbance at 535 and $572 \mathrm{~nm}$ using a microplate spectrophotometer reader. The results were reported as $\mathrm{nM} / \mathrm{mg}$ of protein (34). 
Superoxide anion production. A nitroblue tetrazolium (NBT) assay was used to determine the production of superoxide anion in dorsal back skin tissue homogenates $(10 \mathrm{mg} / \mathrm{ml}$ in $1.15 \% \mathrm{KCl}$ ), following a previously described protocol (35). Briefly, NBT ( $1 \mathrm{mg} / \mathrm{ml}$; Sigma-Aldrich; Merck KGaA) was added to $50 \mu \mathrm{l}$ homogenate at $37^{\circ} \mathrm{C}$ for $1 \mathrm{~h}$. The supernatant was then removed and reduced formazan was solubilized following addition of $120 \mu 12 \mathrm{M} \mathrm{KOH}$ and $140 \mu \mathrm{l}$ dimethyl sulfoxide. NBT reduction was measured at $600 \mathrm{~nm}$ using a microplate spectrophotometer reader and data were normalized to the protein content.

Reverse transcription-quantitative polymerase chain reaction $(R T-q P C R)$. Total RNA in the individual dorsal back skins, sampled by skin puncher $24 \mathrm{~h}$ following the final administration of PCP or PCS, was extracted using TRIzol reagent (Invitrogen; Thermo Fisher Scientific, Inc.) according to a previously described method (30). RNA concentration and quality was determined using a CFX $96^{\mathrm{TM}}$ Real-Time system using iTaq $^{\mathrm{TM}}$ SYBR-Green (both from Bio-Rad Laboratories, Inc., Hercules, CA, USA). To remove contaminating DNA, samples were treated with recombinant DNase I (DNA-free DNA Removal kit; Ambion; Thermo Fisher Scientific, Inc.). RNA was reverse-transcribed using the High-Capacity cDNA Reverse Transcription kit (Applied Biosystems; Thermo Fisher Scientific, Inc.) following the manufacturer's instructions. The PCR cycling conditions were as follows: Initial pre-denaturation of $95^{\circ} \mathrm{C}$ for $1 \mathrm{~min}$, denaturation for $15 \mathrm{sec}$, annealing of $55-65^{\circ} \mathrm{C}$ for $20 \mathrm{sec}$ and extension of $72^{\circ} \mathrm{C}$ for $30 \mathrm{sec}$. A total of 50 cycles were performed. The $\beta$-actin mRNA level was used as a control for tissue integrity in all samples. Primer sequences for Has 1, 2 and 3, COL1A1 and 2, MMP-1, 9 and 13, Nox2, GSH reductase and $\beta$-actin are presented in Table I. For quantitative analysis, the intact control skin tissue was used as the control, and the relative expression of Has 1, 2 and 3, COL1A1 and 2, MMP-1, 9 and 13, Nox2, GSH reductase was calculated using the $2^{-\Delta \Delta \mathrm{Cq}}$ method (36).

Histopathology. Samples from dorsal back skins were separated, fixed in $10 \%$ neutral buffered formalin at room temperature for $24 \mathrm{~h}$, embedded in paraffin wax, cut into sections 3-4 $\mu \mathrm{m}$ thick and stained with hematoxylin and eosin (H\&E) for general histopathology or Masson's trichrome (MT) to detect collagen fiber, according to previously established methods (37). The histopathological profiles of each sample were observed under a light microscope (Model 80i; Nikon Corporation, Tokyo, Japan). To quantify changes in further detail, the number of microfolds formed on the surface of epithelium (folds/mm epithelium), mean epithelial thickness ( $\mu$ m/epithelium) and mean numbers of inflammatory cells infiltrated in the dermis (cells $/ \mathrm{mm}^{2}$ of dermis) were determined in general histomorphometrical analysis using image analysis software (iSolution FL ver 9.1; IMT i-solution Inc., Vancouver, Canada) under H\&E staining and in collagen fiber-occupied regions of the dermis $\left(\% / \mathrm{mm}^{2}\right.$ of dermis) under MT staining. The histopathologist was blinded to the group distribution when conducting the analysis.

Immunohistochemistry. Following dewaxing of the prepared skin histological paraffin wax sections, citrate buffer antigen
Table I. Primer sequences for reverse transcription-quantitative polymerase chain reaction.

\begin{tabular}{ll}
\hline Target & Primer sequence (5'-3') \\
\hline Has 1 & \\
Forward & GCATGGGCTATGCTACCAAGTAT \\
Reverse & AGGAGGGCGTCTCCGAGTA
\end{tabular}

Has 2

Forward GACCCTATGGTTGGAGGTGTTG

Reverse ACGCTGCTGAGGAAGGAGATC

Has 3

Forward AGACCGAGCTAGCCTTCCTAGT

Reverse TAATGGCCAGATACAGCATGAG

COL1A1

Forward

Reverse

GCGGTAACGATGGTGCTGTT

COL1A2

Forward

CTTCACCCTTAGCACCAAC

Reverse

ATTGTCGCCAGTGAG

MMP-1

Forward CTGGTCCTGCTGGT

Reverse

AAGGTTAGCTTACTGTCACACGCTT

MMP-9

Forward

CGACTCTAGAAACACAAGAGCAAGA

Reverse

CCCGGACCAAGGATACAG

MMP-13

Forward

GGCTTTCTCTCGGTACTG

Reverse

CATCCATCCCGTGACCTTAT

GCATGACTCTCACAATGCGA

GSH

reductase

Forward

Reverse

TGCGTGAATGTTGGATGTGTACCC

Nox2

Forward CCGGCATTCTCCAGTTCCTCG

Reverse

AGCTATGAGGTGGTGATGTTAGTGG

$\beta$-actin

Forward CACAATATTTGTACCAGACAGACTTGAG

Reverse

AGCTGCGTTTTACACCCTTT

AAGCCATGCCAATGTTGTCT

Has, hyaluronic acid synthase; COL1A, collagen, type I $\alpha$; MMP, matrix metalloproteinase; GSH reductase, glutathione reductase; Nox2, gp91phox subunit of the phagocyte NADPH oxidase.

(epitope) retrieval pretreatment was conducted (37). Briefly, a water bath was pre-heated to $95-100^{\circ} \mathrm{C}$ with a staining dish containing $10 \mathrm{mM}$ citrate buffer (pH 6.0). Slides were immersed in the staining dish for $20 \mathrm{~min}$ and the lid was placed loosely. The staining dish was then kept at room temperature for $20 \mathrm{~min}$ to cool. Sections were immunostained using avidin-biotin complex (ABC) methods for caspase-3, cleaved poly(ADP-ribose) polymerase (PARP), nitrotyrosine (NT), 4-hydroxynonenal (4-HNE), inducible nitrogen oxide synthase (iNOS) and matrix metalloproteinase (MMP)-9 
Table II. Primary antiserum and detection kits used in the present study.

\begin{tabular}{|c|c|c|c|}
\hline Product & $\begin{array}{l}\text { Catalog } \\
\text { no. }\end{array}$ & Supplier & Dilution \\
\hline \multicolumn{4}{|l|}{ Primary antiserums } \\
\hline $\begin{array}{l}\text { Anti-cleaved caspase-3 (Asp175) } \\
\text { polyclonal antibody }\end{array}$ & 9661 & $\begin{array}{l}\text { Cell Signaling Technology Inc., } \\
\text { Danvers, MA, USA }\end{array}$ & $1: 400$ \\
\hline $\begin{array}{l}\text { Anti-cleaved poly(ADP-ribose) polymerase } \\
\text { (Asp214) specific antibody }\end{array}$ & 9545 & $\begin{array}{l}\text { Cell Signaling Technology Inc., } \\
\text { Danvers, MA, USA }\end{array}$ & $1: 100$ \\
\hline Anti-4-Hydroxynonenal polyclonal antibody & Ab46545 & Abcam, Cambridge, UK & $1: 100$ \\
\hline Anti-Nitrotyrosine polyclonal antibody & $06-284$ & EMD Millipore, Billerica, MA, USA & $1: 200$ \\
\hline Anti-Matrix metalloprotease- 9 mouse antibody & Ab38898 & Abcam, Cambridge, UK & $1: 100$ \\
\hline \multicolumn{4}{|l|}{ Detection kits } \\
\hline Vectastain Elite ABC kit & PK-6200 & Vector Laboratories, Inc., Burlingame, CA, USA & $1: 50$ \\
\hline Peroxidase substrate kit & SK-4100 & Vector Laboratories, Inc., Burlingame, CA, USA & $1: 50$ \\
\hline
\end{tabular}

All antiserums were diluted with $0.01 \mathrm{M}$ phosphate buffered saline.

according to the results of a previous study (37). Briefly, endogenous peroxidase activity was blocked by incubation in methanol and $0.3 \% \mathrm{H}_{2} \mathrm{O}_{2}$ at room temperature for $30 \mathrm{~min}$ and non-specific binding was blocked with $1 \%$ normal horse serum blocking solution (dilution, 1:100; Vector Laboratories, Peterborough, UK) for $1 \mathrm{~h}$ in a humidity chamber. Sections were incubated with primary antibodies (listed in Table II) overnight at $4^{\circ} \mathrm{C}$ in a humidity chamber and then incubated with biotinylated universal secondary antibody (dilution, 1:50; Vector Laboratories) using a Vectastain Elite ABC kit (dilution, 1:50; Vector Laboratories; Table II) for $1 \mathrm{~h}$ at room temperature in a humidity chamber acooriding to the manufacturer's instructions. Finally, sections were incubated with a peroxidase substrate kit (Vector Laboratories; Table II) for $3 \mathrm{~min}$ at room temperature according to the manufacturer's instructions. Between steps, all sections were rinsed in $0.01 \mathrm{M}$ PBS. Cells or fibers comprising $>30 \%$ immunoreactivity for each antiserum compared with intact dermal keratinocytes or dermal tissue, were regarded as positive. The mean numbers of caspase-3, PARP, NT and 4-HNE-immunoreactive epithelial cells (\%, cells/100 epithelial cells) were counted using an established automated image analysis process (37). Additionally, the percentage of the dermis occupied by MMP-9 immunoreactive fibers was calculated $\left(\% / \mathrm{mm}^{2}\right.$ dermis). The histopathologist was blinded to the group distribution when performing the analysis.

Statistical analyses. All data are presented as the mean \pm standard deviation of eight hairless mice. Multiple comparison tests of the different groups were conducted. Variance homogeneity was examined using the Levene test and if no significant deviation from variance homogeneity was detected, the data were analyzed by a one-way analysis of variance followed by a Least Significant Difference multi-comparison test to determine whether differences between pairs of groups were significant. If significant deviations from variance homogeneity were detected by the Levene test, the non-parametric Kruskal-Wallis $\mathrm{H}$ comparison test was conducted. When a significant difference was observed in the Kruskal-Wallis $\mathrm{H}$ test, the Mann-Whitney U test with Bonferroni correction was used to determine whether there were significant differences between specific pairs of groups. Statistical analyses were performed using SPSS software ver. 14.0 for Windows (SPSS, Inc., Chicago, IL, USA) and $\mathrm{P}<0.05$ was considered to indicate a significant difference.

\section{Results}

PCP decreases wrinkle formation in UVB-exposed mice. To confirm the wrinkle alleviation effect of PCP, the mean length and depth of the wrinkles were measured (Fig. 1). It was determined that the mean length and depth of the wrinkles were significantly greater in the skin of the UVB-exposed control mice compared with the intact control (both $\mathrm{P}<0.01$; Fig. 2). However, these increases in wrinkle formations significantly decreased following oral administration of PCP compared with the UVB control (all $\mathrm{P}<0.05)$. These decreases occurred in a dose-dependent manner (Fig. 2).

$P C P$ decreases $U V B$-induced skin edema in UVB-exposed mice. The effect of PCP against UVB-induced skin edema was analyzed by measuring 6-mm-diameter skin weights (edema score). The 6-mm-diameter skin weights (edema score) in mice exposed to UVB were significantly greater than those of intact controls $(\mathrm{P}<0.01)$. However, in mice treated with 400, 200 and $100 \mathrm{mg} / \mathrm{kg}$ PCP, mean skin weight significantly decreased $(\mathrm{P}<0.01)$ compared with those of the UVB-exposed mice, by $-55.33,-45.68$ and $-37.61 \%$, respectively (Fig. 3).

PCP increases skin water content in UVB-exposed mice. To clarify the moisturizing effects of PCP, the skin water content in 6-mm-diameter tissues was observed. Skin-water content was significantly decreased following UVB treatment $(\mathrm{P}<0.01)$. However, UVB-induced decreases in skin water contents were significantly reversed $(\mathrm{P}<0.01)$ following 

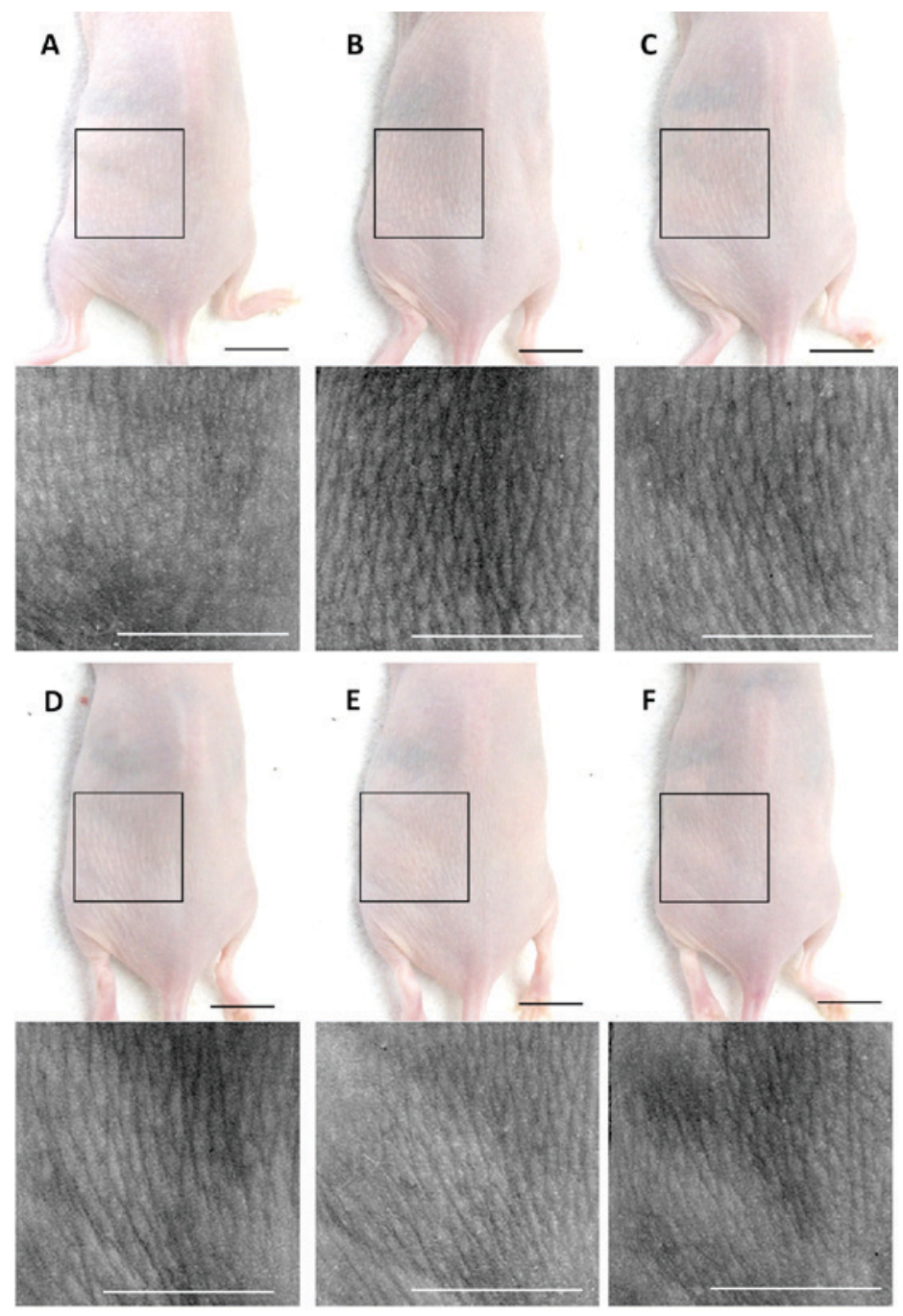

Figure 1. Representative gross images of dorsal back skin (top panel) and replicas (bottom panel) taken from unexposed intact or UVB-exposed hairless mice. (A) Unexposed normal vehicle control hairless mice treated with distilled water; (B) UVB-exposed vehicle control hairless mice administered distilled water; (C) UVB-exposed hairless mice administered $2 \mathrm{ml} / \mathrm{kg}$ PCS; (D) UVB-exposed hairless mice administered $100 \mathrm{mg} / \mathrm{kg}$ PCP; (E) UVB-exposed hairless mice administered $200 \mathrm{mg} / \mathrm{kg}$ PCP; (F) UVB-exposed hairless mice administered $400 \mathrm{mg} / \mathrm{kg}$ PCP. Scale bars=10 mm; UVB, ultraviolet B; PCP, dried pomegranate juice concentrated powder; PCS, pomegranate juice concentrated solution.
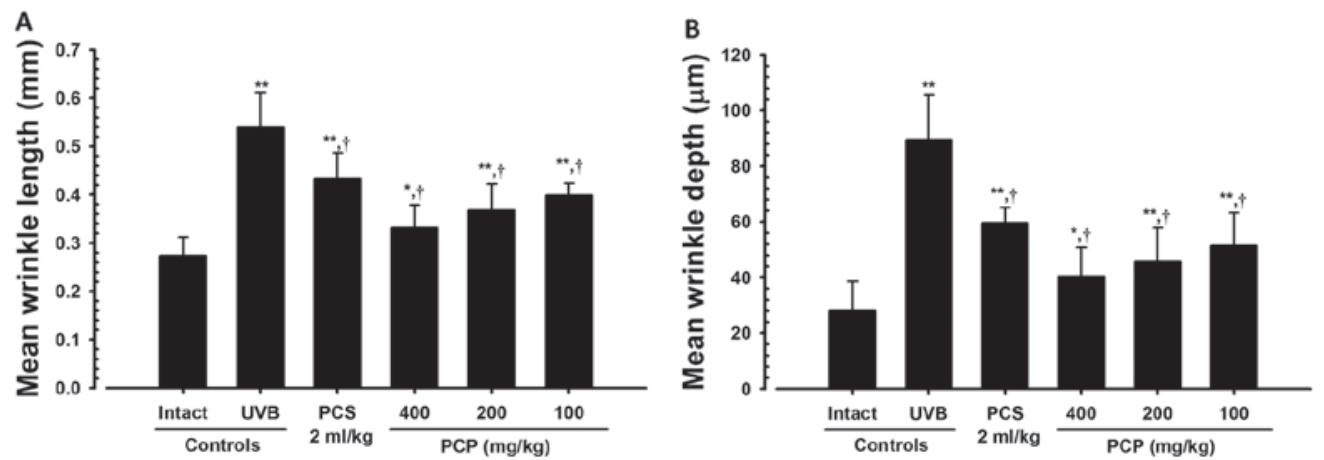

Figure 2. Changes in the mean length and depth of wrinkles in skin replicas following 15 weeks continuous oral administration of PCP or PCS in UVB-exposed mice. Significant increases in (A) mean length and (B) average depth of skin wrinkles were detected in the skin replicas of UVB control mice compared with the intact controls. Values are expressed as the mean \pm standard deviation $(n=8)$. P-values were determined by the least significant difference test. ${ }^{*} \mathrm{P}<0.05$ and ${ }^{* *} \mathrm{P}<0.01$ vs. intact control; ${ }^{\dagger} \mathrm{P}<0.01$ vs. UVB control. UVB, ultraviolet B; PCP, dried pomegranate juice concentrated powder; PCS, pomegranate juice concentrated solution.

treatment with 100, 200 and $400 \mathrm{mg} / \mathrm{kg} \mathrm{PCP}$, in a dose-dependent manner. Additionally, mice administered $2 \mathrm{ml} / \mathrm{kg}$ PCS exhibited significant increases in skin water content compared with UVB control mice $(\mathrm{P}<0.01$; Table III). 
Table III. Changes in skin water, COL1 and hyaluronan contents following 15 weeks continuous oral administration of PCP or PCS in UVB-exposed mice.

\begin{tabular}{|c|c|c|c|}
\hline Groups & $\begin{array}{l}\text { Skin water contents } \\
\text { (\%/6 mm-diameter skin })\end{array}$ & $\begin{array}{l}\text { Skin COL1 } \\
\text { contents }(\%)\end{array}$ & $\begin{array}{l}\text { Skin hyaluronan } \\
\text { contents }(\mathrm{ng} / \mathrm{ml})\end{array}$ \\
\hline \multicolumn{4}{|l|}{ Controls } \\
\hline Intact & $37.14 \pm 3.47$ & $98.61 \pm 14.32$ & $2.51 \pm 0.54$ \\
\hline UVB & $17.96 \pm 3.05^{\mathrm{a}}$ & $44.41 \pm 10.53^{\mathrm{a}}$ & $1.01 \pm 0.18^{\mathrm{a}}$ \\
\hline \multicolumn{4}{|l|}{ Reference } \\
\hline $\mathrm{PCS} 2 \mathrm{ml} / \mathrm{kg}$ & $26.54 \pm 2.80^{a, b}$ & $58.16 \pm 5.50^{\mathrm{a}, \mathrm{b}}$ & $1.35 \pm 0.20^{\mathrm{a}, \mathrm{b}}$ \\
\hline \multicolumn{4}{|l|}{ PCP } \\
\hline $100 \mathrm{mg} / \mathrm{kg}$ & $26.74 \pm 2.42^{\mathrm{a}, \mathrm{b}}$ & $58.82 \pm 7.44^{\mathrm{a}, \mathrm{b}}$ & $1.42 \pm 0.14^{\mathrm{a}, \mathrm{b}}$ \\
\hline $200 \mathrm{mg} / \mathrm{kg}$ & $29.66 \pm 3.31^{\mathrm{a}, \mathrm{b}}$ & $65.34 \pm 8.57^{\mathrm{a}, \mathrm{b}}$ & $1.68 \pm 0.21^{\mathrm{a}, \mathrm{b}}$ \\
\hline $400 \mathrm{mg} / \mathrm{kg}$ & $32.18 \pm 2.86^{\mathrm{a}, \mathrm{b}}$ & $73.83 \pm 6.30^{\mathrm{a}, \mathrm{b}}$ & $1.82 \pm 0.21^{\mathrm{a}, \mathrm{b}}$ \\
\hline
\end{tabular}

Values are expressed as mean \pm standard deviation $(\mathrm{n}=8) .{ }^{\mathrm{a}} \mathrm{P}<0.01$ vs. intact control; ${ }^{\mathrm{b}} \mathrm{P}<0.01 \mathrm{vs}$. UVB control. UVB, ultraviolet $\mathrm{B}$; PCS, pomegranate juice concentrated solution; PCP, dried pomegranate juice concentrated powder; COL1, collagen type I.

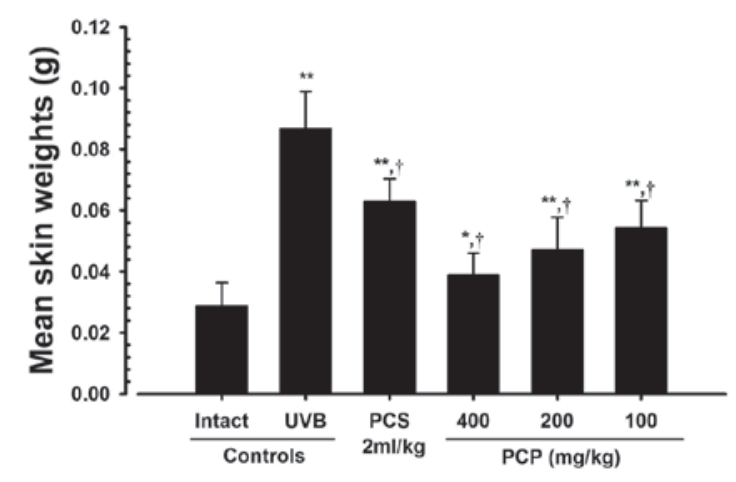

Figure 3. Changes in skin edema scores. The graph presents the 6-mm diameter skin weights following 15 weeks continuous oral administration of PCP or PCS in UVB-exposed mice. Values are expressed the mean \pm standard deviation $(n=8)$. P-values were determined by the least significant difference test. ${ }^{*} \mathrm{P}<0.05$ and ${ }^{* *} \mathrm{P}<0.01$ vs. intact control; ${ }^{\dagger} \mathrm{P}<0.01$ vs. UVB control. UVB, ultraviolet B; PCP, dried pomegranate juice concentrated powder; PCS, pomegranate juice concentrated solution.

PCP inhibits the decreases in skin COL1 and hyaluronan content in UVB-exposed mice. To confirm the moisturizing effects of PCP, changes in COL1 and hyaluronan contents were assessed. COL1 and hyaluronan contents were significantly lower in 6-mm-diameter skin tissues from UVB control mice compared with intact controls $(\mathrm{P}<0.01)$. However, these decreases were significantly inhibited following oral administration of all three doses of PCP $(\mathrm{P}<0.01$; Table III).

PCP decreases MPO activity and IL-1 $\beta$ levels while increasing IL-10 levels in UVB-exposed mice. To clarify the anti-inflammatory effects of PCP, MPO activity, as well as IL-1 $\beta$ and IL-10 levels, were assessed. Skin MPO activity and IL-1 $\beta$ levels were significantly higher in UVB-exposed control mice than intact control mice $(\mathrm{P}<0.01)$. MPO activity and IL-1 $\beta$ levels were significantly inhibited following oral administration of PCS $(\mathrm{P}<0.01)$ and all doses of PCP $(\mathrm{P}<0.01)$ in a dose-dependent manner, compared with the UVB control mice (Table IV). IL-10 levels in UVB-exposed control mice were significantly decreased compared with those in unexposed intact control mice $(\mathrm{P}<0.01)$. However, significant $(\mathrm{P}<0.05)$ and dose-dependent increases in skin IL-10 levels were observed following administration of all three doses of PCP compared with untreated UVB-exposed mice (Table IV).

PCP increases GSH content and decreases MDA levels in $U V B$-exposed mice. To determine the anti-oxidative effects of PCP, GSH contents and MDA levels were analyzed. GSH contents were significantly lower in the UVB-exposed mice compared with the intact control $(\mathrm{P}<0.01$; Table $\mathrm{V})$. Furthermore, significant increases in skin MDA levels, indicating increased lipid peroxidation and superoxide anion production, were detected in UVB-exposed mice compared with unexposed control mice $(\mathrm{P}<0.01$; Table $\mathrm{V})$.

Skin GSH contents were significantly increased in all PCP-administered hairless mice compared with UVB control mice $(\mathrm{P}<0.01$; Table $\mathrm{V})$. This increase occurred in a dose-dependent manner. Furthermore, skin MDA levels and superoxide anion production were significantly decreased in PCP-treated mice compared with UVB control mice $(\mathrm{P}<0.01$; Table V).

PCP decreases skin MMP-1, -9, and -13 and Nox2 mRNA expression in UVB-exposed mice. Although no significant changes in skin Has 1, 2, and 3 or in COL1A1 and 2 mRNA levels (relative to the control) were identified in UVB-exposed control mice compared with unexposed intact control mice, significant increases $(\mathrm{P}<0.01)$ in skin Has 1,2 , and 3 and COL1A1 and 2 mRNA levels were detected in mice receiving the three doses of $\mathrm{PCP}$, compared with UVB control mice, suggesting that PCP increases hyaluronan and COL1 synthesis (Table VI).

Significant increases in skin MMP-1, -9 and -13 and Nox2 mRNA levels were detected in UVB-exposed control mice compared with unexposed intact mice $(\mathrm{P}<0.01)$, indicating increased MMP activity and ROS-dependent inflammation in UVB-exposed control mice. However, levels of skin MMP and 
Table IV. Changes in skin MPO activity, IL-1 $\beta$ and IL-10 levels following 15 weeks continuous oral administration of PCP or PCS in UVB-exposed mice.

\begin{tabular}{|c|c|c|c|}
\hline Groups & $\begin{array}{c}\text { MPO (Numbers of } \\
\text { neutrophils } \times 10^{5} / \mathrm{mg} \text { protein) }\end{array}$ & $\begin{array}{c}\text { IL-1 } \beta \\
\text { (pg/100 mg protein) }\end{array}$ & $\begin{array}{c}\text { IL-10 } \\
\text { (pg/100 mg protein) }\end{array}$ \\
\hline \multicolumn{4}{|l|}{ Controls } \\
\hline Intact & $1.41 \pm 0.42$ & $20.43 \pm 3.28$ & $318.88 \pm 72.13$ \\
\hline UVB & $11.14 \pm 2.38^{\mathrm{a}}$ & $62.10 \pm 11.63^{\mathrm{a}}$ & $146.63 \pm 30.91^{\mathrm{a}}$ \\
\hline \multicolumn{4}{|l|}{ Reference } \\
\hline PCS 2 ml/kg & $7.77 \pm 1.72^{\mathrm{a}, \mathrm{b}}$ & $42.63 \pm 5.49^{\mathrm{a}, \mathrm{b}}$ & $192.63 \pm 8.85^{\mathrm{a}, \mathrm{b}}$ \\
\hline \multicolumn{4}{|l|}{ PCP } \\
\hline $100 \mathrm{mg} / \mathrm{kg}$ & $7.38 \pm 1.60^{\mathrm{a}, \mathrm{b}}$ & $41.53 \pm 11.02^{\mathrm{a}, \mathrm{b}}$ & $211.00 \pm 44.98^{\mathrm{a}, \mathrm{c}}$ \\
\hline $200 \mathrm{mg} / \mathrm{kg}$ & $4.84 \pm 1.40^{\mathrm{a}, \mathrm{b}}$ & $37.31 \pm 12.16^{\mathrm{a}, \mathrm{b}}$ & $229.63 \pm 33.41^{\mathrm{b}, \mathrm{d}}$ \\
\hline $400 \mathrm{mg} / \mathrm{kg}$ & $4.41 \pm 1.19^{\mathrm{a}, \mathrm{b}}$ & $31.21 \pm 10.85^{\mathrm{b}, \mathrm{d}}$ & $238.00 \pm 24.37^{\mathrm{b}, \mathrm{d}}$ \\
\hline
\end{tabular}

Values are expressed as mean \pm standard deviation $(\mathrm{n}=8) .{ }^{\mathrm{a}} \mathrm{P}<0.01$ vs. intact control; ${ }^{\mathrm{b}} \mathrm{P}<0.01 \mathrm{vs}$. UVB control; ${ }^{\mathrm{c}} \mathrm{P}<0.05$ vs. UVB control; ${ }^{\mathrm{d}} \mathrm{P}<0.05$ vs. intact control. IL, interleukin; MPO, myeloperoxidase; UVB, ultraviolet B; PCP, dried pomegranate juice concentrated powder; PCS, pomegranate juice concentrated solution.

Table V. Changes in the skin antioxidant defense systems following 15 weeks continuous oral administration of PCP or PCS in UVB-exposed mice.

Nox2 mRNA were significantly inhibited following administration of all three doses of PCP compared with UVB control mice $(\mathrm{P}<0.01$; Table VI).

Levels of skin GSH reductase mRNA were significantly decreased in UVB-exposed mice compared with intact control mice $(\mathrm{P}<0.01)$. However, significant dose-dependent increases in skin GSH reductase mRNA expression were detected in mice receiving 100, 200 and $400 \mathrm{mg} / \mathrm{kg}$ PCP compared with UVB control mice $(\mathrm{P}<0.01$; Table VI).

PCP decreases histopathological dermis sclerosis and inflammatory signs in $U V B$-exposed mice. When the mean epithelial thicknesses of UVB-exposed mice and intact control mice were compared, it was determined that UVB-exposed control mice exhibited higher mean epithelial thicknesses of dorsal back skin tissues compared with intact control mice. In addition, there was a cellular infiltration of inflammatory cells into the epidermis, an abnormal accumulation of collagen in the dermis and the formation of microfolds on the surface of the epithelial lining was observed (Fig. 4).

These findings were confirmed by histomorphometric analysis; significant increases in the number of epithelial surface microfolds, mean epithelial thickness, numbers of dermal infiltrating inflammatory cells and the percentages of collagen fiber-occupied dermal regions were detected in UVB-exposed mice compared with unexposed intact vehicle controls $(\mathrm{P}<0.01)$. However, significant dose-dependent decreases in UVB-induced histopathological dermis sclerosis and inflammatory signs were observed in mice orally administered 100, 200 and $400 \mathrm{mg} / \mathrm{kg}$ PCP compared with UVB 
Table VI. Changes in skin mRNA expression following 15 weeks continuous oral administration of PCP or PCS in UVB-exposed mice.

\begin{tabular}{|c|c|c|c|c|c|c|}
\hline \multirow[b]{2}{*}{ Groups } & \multicolumn{2}{|c|}{ Control } & \multirow{2}{*}{$\begin{array}{c}\text { Reference } \\
\text { PCS } 2 \mathrm{ml} / \mathrm{kg}\end{array}$} & \multicolumn{3}{|c|}{ PCP } \\
\hline & Intact & UVB & & $100 \mathrm{mg} / \mathrm{kg}$ & $200 \mathrm{mg} / \mathrm{kg}$ & $400 \mathrm{mg} / \mathrm{kg}$ \\
\hline Has 1 & $1.02 \pm 0.11$ & $1.03 \pm 0.21$ & $1.85 \pm 0.32^{\mathrm{a}, \mathrm{b}}$ & $2.41 \pm 0.37^{\mathrm{a}, \mathrm{b}}$ & $2.91 \pm 0.55^{\mathrm{a}, \mathrm{b}}$ & $3.89 \pm 1.17^{\mathrm{a}, \mathrm{b}}$ \\
\hline Has 2 & $1.05 \pm 0.11$ & $0.99 \pm 0.11$ & $1.59 \pm 0.22^{\mathrm{a}, \mathrm{b}}$ & $1.79 \pm 0.27^{\mathrm{a}, \mathrm{b}}$ & $2.25 \pm 0.41^{\mathrm{a}, \mathrm{b}}$ & $4.10 \pm 1.23^{\mathrm{a}, \mathrm{b}}$ \\
\hline Has 3 & $1.05 \pm 0.15$ & $0.98 \pm 0.11$ & $1.58 \pm 0.41^{\mathrm{a}, \mathrm{b}}$ & $1.71 \pm 0.34^{\mathrm{a}, \mathrm{b}}$ & $3.05 \pm 0.93^{\mathrm{a}, \mathrm{b}}$ & $3.67 \pm 1.70^{\mathrm{a}, \mathrm{b}}$ \\
\hline COL1A1 & $1.00 \pm 0.12$ & $0.97 \pm 0.20$ & $2.60 \pm 0.41^{\mathrm{a}, \mathrm{b}}$ & $3.03 \pm 0.56^{\mathrm{a}, \mathrm{b}}$ & $3.75 \pm 0.99^{\mathrm{a}, \mathrm{b}}$ & $4.76 \pm 1.62^{\mathrm{a}, \mathrm{b}}$ \\
\hline COL1A2 & $1.01 \pm 0.14$ & $1.00 \pm 0.09$ & $2.62 \pm 0.45^{\mathrm{a}, \mathrm{b}}$ & $3.01 \pm 0.54^{\mathrm{a}, \mathrm{b}}$ & $3.74 \pm 0.98^{\mathrm{a}, \mathrm{b}}$ & $4.73 \pm 1.85^{\mathrm{a}, \mathrm{b}}$ \\
\hline MMP-1 & $1.01 \pm 0.08$ & $2.05 \pm 0.21^{\mathrm{a}}$ & $1.71 \pm 0.24^{\mathrm{a}, \mathrm{b}}$ & $1.63 \pm 0.19^{\mathrm{a}, \mathrm{b}}$ & $1.51 \pm 0.24^{\mathrm{a}, \mathrm{b}}$ & $1.33 \pm 0.26^{\mathrm{a}, \mathrm{b}}$ \\
\hline MMP-9 & $1.02 \pm 0.07$ & $1.91 \pm 0.21^{\mathrm{a}}$ & $1.65 \pm 0.15^{\mathrm{a}, \mathrm{b}}$ & $1.55 \pm 0.18^{\mathrm{a}, \mathrm{b}}$ & $1.37 \pm 0.16^{\mathrm{a}, \mathrm{b}}$ & $1.24 \pm 0.11^{\mathrm{a}, \mathrm{b}}$ \\
\hline MMP-13 & $0.95 \pm 0.08$ & $2.57 \pm 0.47^{\mathrm{a}}$ & $1.95 \pm 0.21^{\mathrm{a}, \mathrm{c}}$ & $1.86 \pm 0.22^{\mathrm{a}, \mathrm{b}}$ & $1.65 \pm 0.19^{\mathrm{a}, \mathrm{b}}$ & $1.40 \pm 0.11^{\mathrm{a}, \mathrm{b}}$ \\
\hline GSH reductase & $1.18 \pm 0.34$ & $0.57 \pm 0.14^{\mathrm{a}}$ & $0.76 \pm 0.11^{\mathrm{a}, \mathrm{b}}$ & $0.84 \pm 0.12^{\mathrm{b}}$ & $1.07 \pm 0.17^{\mathrm{b}}$ & $1.21 \pm 0.18^{\mathrm{b}}$ \\
\hline Nox2 & $1.05 \pm 0.14$ & $2.02 \pm 0.27^{\mathrm{a}}$ & $1.52 \pm 0.19^{\mathrm{a}, \mathrm{b}}$ & $1.49 \pm 0.16^{\mathrm{a}, \mathrm{b}}$ & $1.41 \pm 0.14^{\mathrm{a}, \mathrm{b}}$ & $1.27 \pm 0.17^{\mathrm{b}, \mathrm{d}}$ \\
\hline
\end{tabular}

Values are expressed as mean \pm standard deviation $(\mathrm{n}=8)$, relative expression $/ \beta$-actin mRNA. ${ }^{\mathrm{a}} \mathrm{P}<0.01$ vs. intact control; ${ }^{\text {b }} \mathrm{P}<0.01 \mathrm{vs}$. UVB control; ${ }^{\mathrm{c}} \mathrm{P}<0.05$ vs. UVB control; ${ }^{\mathrm{d}} \mathrm{P}<0.05$ vs. intact control. UVB, ultraviolet B; COL1, collagen, type I; COL1A1, COL1 $\alpha 1 ;$ COL1A2, $\mathrm{COL1}, \alpha$ 2; GSH, glutathione; Has, hyaluronic acid synthase; MMP, matrix metalloproteinase; Nox2, gp91phox subunit of the phagocyte NADPH oxidase; PCP, dried pomegranate juice concentrated powder; PCS, pomegranate juice concentrated solution.

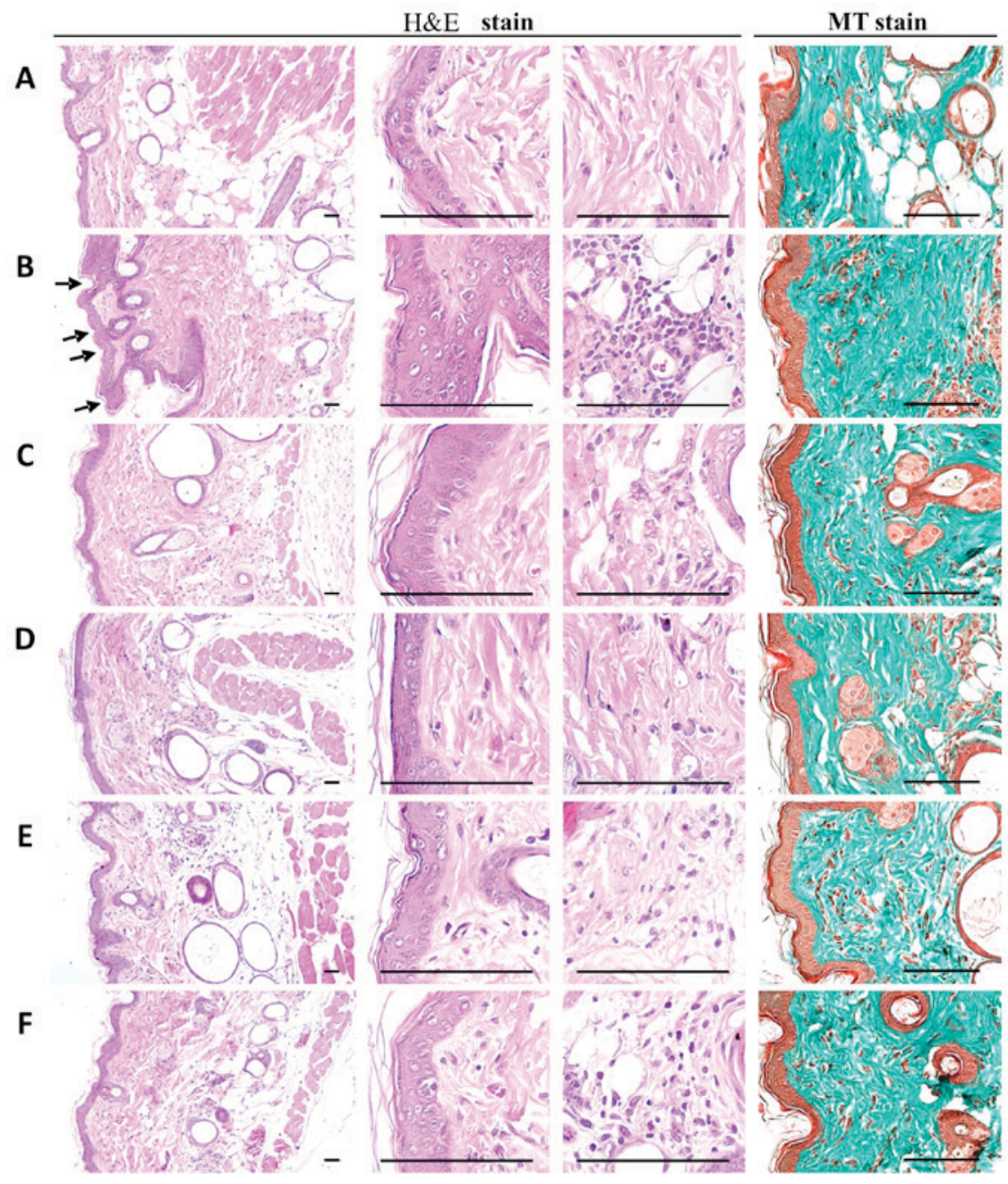

Figure 4. Representative histological images of dorsal back skin tissues taken from unexposed intact or UVB exposed hairless mice. (A) Intact vehicle control; (B) UVB control; (C) UVB-exposed mice treated with $2 \mathrm{ml} / \mathrm{kg}$ PCS; (D) UVB-exposed mice treated with $100 \mathrm{mg} / \mathrm{kg}$ PCP; (E) UVB-exposed mice treated with $200 \mathrm{mg} / \mathrm{kg}$ PCP; (F) UVB-exposed mice treated with $400 \mathrm{mg} / \mathrm{kg}$ PCP. Arrows indicate microfolds formed. Scale bars=100 $\mu \mathrm{m}$. UVB, ultraviolet B; MT, Masson's trichrome; PCP, dried pomegranate juice concentrated powder; PCS, pomegranate juice concentrated solution. 
Table VII. General histomorphometrical analysis of skin following 15 weeks continuous oral administration of PCP or PCS in UVB-exposed mice.

\begin{tabular}{|c|c|c|c|c|}
\hline Groups & $\begin{array}{c}\text { No. of microfolds } \\
\text { (folds/mm of epidermis) }\end{array}$ & $\begin{array}{l}\text { Mean epithelial thickness } \\
\qquad(\mu \mathrm{m} \text { /epidermis })\end{array}$ & $\begin{array}{l}\text { Mean inflammatory cells } \\
\left.\text { (cells } / \mathrm{mm}^{2} \text { of dermis }\right)\end{array}$ & $\begin{array}{l}\text { Collagen fiber occupied regions } \\
\left(\% / \mathrm{mm}^{2} \text { of dermis }\right)\end{array}$ \\
\hline \multicolumn{5}{|l|}{ Controls } \\
\hline Intact & $8.75 \pm 4.40$ & $19.11 \pm 2.12$ & $10.25 \pm 4.20$ & $42.52 \pm 4.59$ \\
\hline UVB & $70.88 \pm 14.38^{\mathrm{a}}$ & $47.39 \pm 8.29^{\mathrm{a}}$ & $241.25 \pm 39.15^{\mathrm{a}}$ & $76.51 \pm 7.06^{\mathrm{a}}$ \\
\hline \multicolumn{5}{|l|}{ Reference } \\
\hline PCS $2 \mathrm{ml} / \mathrm{kg}$ & $46.00 \pm 11.93^{\mathrm{a}, \mathrm{b}}$ & $30.60 \pm 5.51^{\mathrm{a}, \mathrm{b}}$ & $186.93 \pm 24.73^{\mathrm{a}, \mathrm{c}}$ & $64.92 \pm 5.26^{\mathrm{a}, \mathrm{b}}$ \\
\hline \multicolumn{5}{|l|}{ PCP } \\
\hline $100 \mathrm{mg} / \mathrm{kg}$ & $40.75 \pm 10.05^{\mathrm{a}, \mathrm{b}}$ & $29.00 \pm 4.44^{\mathrm{a}, \mathrm{b}}$ & $171.50 \pm 28.35^{\mathrm{a}, \mathrm{b}}$ & $60.98 \pm 10.95^{\mathrm{a}, \mathrm{b}}$ \\
\hline $200 \mathrm{mg} / \mathrm{kg}$ & $33.25 \pm 10.07^{\mathrm{a}, \mathrm{b}}$ & $25.72 \pm 5.61^{\mathrm{b}, \mathrm{d}}$ & $149.38 \pm 32.95^{\mathrm{a}, \mathrm{b}}$ & $58.64 \pm 4.25^{\mathrm{a}, \mathrm{b}}$ \\
\hline $400 \mathrm{mg} / \mathrm{kg}$ & $23.88 \pm 11.24^{\mathrm{a}, \mathrm{b}}$ & $23.86 \pm 4.54^{\mathrm{b}}$ & $113.88 \pm 26.82^{\mathrm{a}, \mathrm{b}}$ & $54.71 \pm 4.28^{\mathrm{a}, \mathrm{b}}$ \\
\hline
\end{tabular}

Values are expressed as mean \pm standard deviation $(\mathrm{n}=8) .{ }^{\mathrm{a}} \mathrm{P}<0.01$ vs. intact control; ${ }^{\mathrm{b}} \mathrm{P}<0.01 \mathrm{vs}$. UVB control; ${ }^{\mathrm{c}} \mathrm{P}<0.05$ vs. UVB control; ${ }^{\mathrm{d}} \mathrm{P}<0.05$ vs. intact control. UVB, ultraviolet $\mathrm{B}$; PCP, dried pomegranate juice concentrated powder; PCS, pomegranate juice concentrated solution.

control mice $(\mathrm{P}<0.01)$. At an oral dose of $2 \mathrm{ml} / \mathrm{kg}$, PCS was also associated with significant decreases in epithelial surface microfolds, mean epithelial thickness, numbers of dermal infiltrating inflammatory cells and percentages of collagen fiber-occupied dermal regions compared with the UVB control $(\mathrm{P}<0.05$; Table VII).

PCP decreases NT-4-HNE-, caspase-3- and PARP-positive cells and decreases dermal MMP-9-immunoreactivity cells in UVB-exposed mice. Notable increases in the number of cells immunolabeled for oxidative stress (NT and 4-HNE) and apoptosis (caspase-3 and PARP) markers were detected among epidermal keratinocytes on the dorsal back skin tissues in UVB-exposed control mice, with marked increases in dermal MMP-9 immunoreactivity (Fig. 5). These changes were confirmed by histomorphometric analyses; significant increases in epithelial NT-, 4-HNE-, caspase-3- and PARP-immunoreactive cells as well as dermal MMP-9 immunoreactivity, were observed in UVB-exposed control mice compared with unexposed control mice $(\mathrm{P}<0.01$; Table VIII). However, significant decreases in oxidative stress and apoptosis markers and dermal MMP-9 immunoreactivity were observed in mice treated with $2 \mathrm{ml} / \mathrm{kg}$ PCS and 100, 200 and $400 \mathrm{mg} / \mathrm{kg}$ PCP compared with UVB-exposed mice $(\mathrm{P}<0.01$; Table VII). In particular, PCP induced clear dose-dependent decreases in epithelial NT-, 4-HNE-, caspase-3- and PARP-positive cells, as well as dermal MMP-9-immunoreactive cells (Table VIII and Fig. 5).

\section{Discussion}

Prolonged human exposure to sunlight results in unwanted and deleterious effects, including the development of cancer, wrinkles, scales, dryness and mottled pigment abnormalities (hyper- or hypopigmentation) (4-6). Furthermore, acute exposure to UV radiation may stimulate the migration of inflammatory cells, such as neutrophils (38). Inflammation may cause skin damage, premature skin aging and skin cancer (39).
Additionally, chronic photoaging triggers marked hyperplasia of epidermal cells with hyperkeratosis, leading to wrinkle formation (40). The results of the current study demonstrated that PCP (100, 200 and $400 \mathrm{mg} / \mathrm{kg}$ ) significantly inhibits UVB-induced wrinkle formation and hyperplasia/hypertrophy of the epithelial keratocytes. Pomegranate extracts contain anthocyanins, ellagitannins and hydrolyzable tannins, and oral administration of these extracts reduces UVB-induced carcinogenesis in mice $(41,42)$. Ellagic acids contained in pomegranates exhibit antimutant, antiviral, antioxidant and skin-whitening activity and are already used in Japan as a food additive (43). It has also been suggested that punic acid in pomegranate seed oil may prevent 7,12-dimethylbenz(a)anthracene (DMBA)- and 12-O-tetradecanoylphorbol-13-acetate (TPA)-induced skin cancer $(44,45)$.

Increased vascular permeability and blood flow are induced by inflammatory chemical mediators, including the cyclooxygenase-derived metabolites of arachidonic acid (46). UVB light-induced edema in hairless mice and erythema in humans can be explained by the same mechanism $(4,6)$. In the current study, the administration of PCP was able to inhibit skin edema in animals exposed to UVB irradiation.

Generally, UVB irradiation stimulates the production of ROS, such as superoxide anions, are important factors (46) in the process of neutrophil recruitment to inflammatory foci. Neutrophils are the first cells to be recruited from the peripheral blood to inflammatory sites $(4,47)$. Inflammatory cells serve an important role in eliminating the causes of inflammation (48), whereas activated polymorphonuclear leukocytes (PMNs) are a potential source of oxygen metabolites and may exacerbate inflammation (49). UVB irradiation increases the activity of MPO, an activating cytotoxic enzyme released from PMNs $(4,14,15,47)$. Thus, reduced neutrophil influx into the skin tissue may be confirmed by a reduction in MPO activity (32). Nox enzymes are involved in the generation of endogenous ROS in response to inflammatory mediators, including cytokines, growth factors and hypoxic conditions $(50,51)$. Nox 2 is predominantly expressed in 
Table VIII. Immuno-histomorphometrical analysis of skin following 15 weeks continuous oral administration of PCP or PCS in UVB-exposed mice.

Epidermal immunoreactive cells (cells/100 epithelial cells)

\begin{tabular}{|c|c|c|c|c|c|}
\hline \multirow[b]{2}{*}{ Groups } & & \multirow{2}{*}{$\begin{array}{c}\text { Dermis MMP-9 } \\
\text { immunoreactivity }(\%)\end{array}$} \\
\hline & NT & 4-HNE & Caspase-3 & PARP & \\
\hline \multicolumn{6}{|l|}{ Controls } \\
\hline Intact & $11.38 \pm 5.83$ & $12.50 \pm 4.87$ & $16.13 \pm 6.64$ & $15.38 \pm 7.33$ & $28.88 \pm 10.82$ \\
\hline UVB & $82.50 \pm 11.17^{\mathrm{a}}$ & $71.75 \pm 10.43^{\mathrm{a}}$ & $83.00 \pm 10.20^{\mathrm{a}}$ & $80.75 \pm 10.98^{a}$ & $75.88 \pm 13.27^{\mathrm{a}}$ \\
\hline \multicolumn{6}{|l|}{ Reference } \\
\hline PCS 2 ml/kg & $52.00 \pm 11.12^{\mathrm{a}, \mathrm{b}}$ & $53.38 \pm 11.86^{\mathrm{a}, \mathrm{b}}$ & $58.25 \pm 10.95^{\mathrm{a}, \mathrm{b}}$ & $52.63 \pm 11.29^{\mathrm{a}, \mathrm{b}}$ & $56.63 \pm 11.48^{\mathrm{a}, \mathrm{b}}$ \\
\hline \multicolumn{6}{|l|}{ PCP } \\
\hline $100 \mathrm{mg} / \mathrm{kg}$ & $47.50 \pm 8.99^{\mathrm{a}, \mathrm{b}}$ & $42.13 \pm 10.36^{\mathrm{a}, \mathrm{b}}$ & $41.25 \pm 10.96^{\mathrm{a}, \mathrm{b}}$ & $43.88 \pm 12.32^{\mathrm{a}, \mathrm{b}}$ & $47.38 \pm 13.14^{\mathrm{a}, \mathrm{b}}$ \\
\hline $200 \mathrm{mg} / \mathrm{kg}$ & $35.00 \pm 6.19^{\mathrm{a}, \mathrm{b}}$ & $38.00 \pm 11.16^{\mathrm{a}, \mathrm{b}}$ & $34.50 \pm 10.38^{\mathrm{a}, \mathrm{b}}$ & $36.38 \pm 10.25^{\mathrm{a}, \mathrm{b}}$ & $42.38 \pm 11.67^{\mathrm{b}, \mathrm{c}}$ \\
\hline $400 \mathrm{mg} / \mathrm{kg}$ & $19.88 \pm 3.23^{\mathrm{b}, \mathrm{c}}$ & $28.13 \pm 12.56^{\mathrm{a}, \mathrm{b}}$ & $24.75 \pm 7.36^{\mathrm{b}}$ & $27.88 \pm 10.37^{\mathrm{b}, \mathrm{c}}$ & $32.75 \pm 12.83^{b}$ \\
\hline
\end{tabular}

Values are expressed as mean \pm standard deviation $(\mathrm{n}=8)$. ${ }^{\mathrm{a}} \mathrm{P}<0.01 \mathrm{vs}$. intact control; ${ }^{\mathrm{b}} \mathrm{P}<0.01 \mathrm{vs}$. UVB control; ${ }^{\mathrm{c}} \mathrm{P}<0.05 \mathrm{vs}$. intact control. $\mathrm{UVB}$, ultraviolet B; PARP, cleaved poly(ADP-ribose) polymerase; NT, nitrotyrosine; 4-HNE, 4-Hydroxynonenal; MMP, matrix metalloproteinase; PCP, dried pomegranate juice concentrated powder; PCS, pomegranate juice concentrated solution.

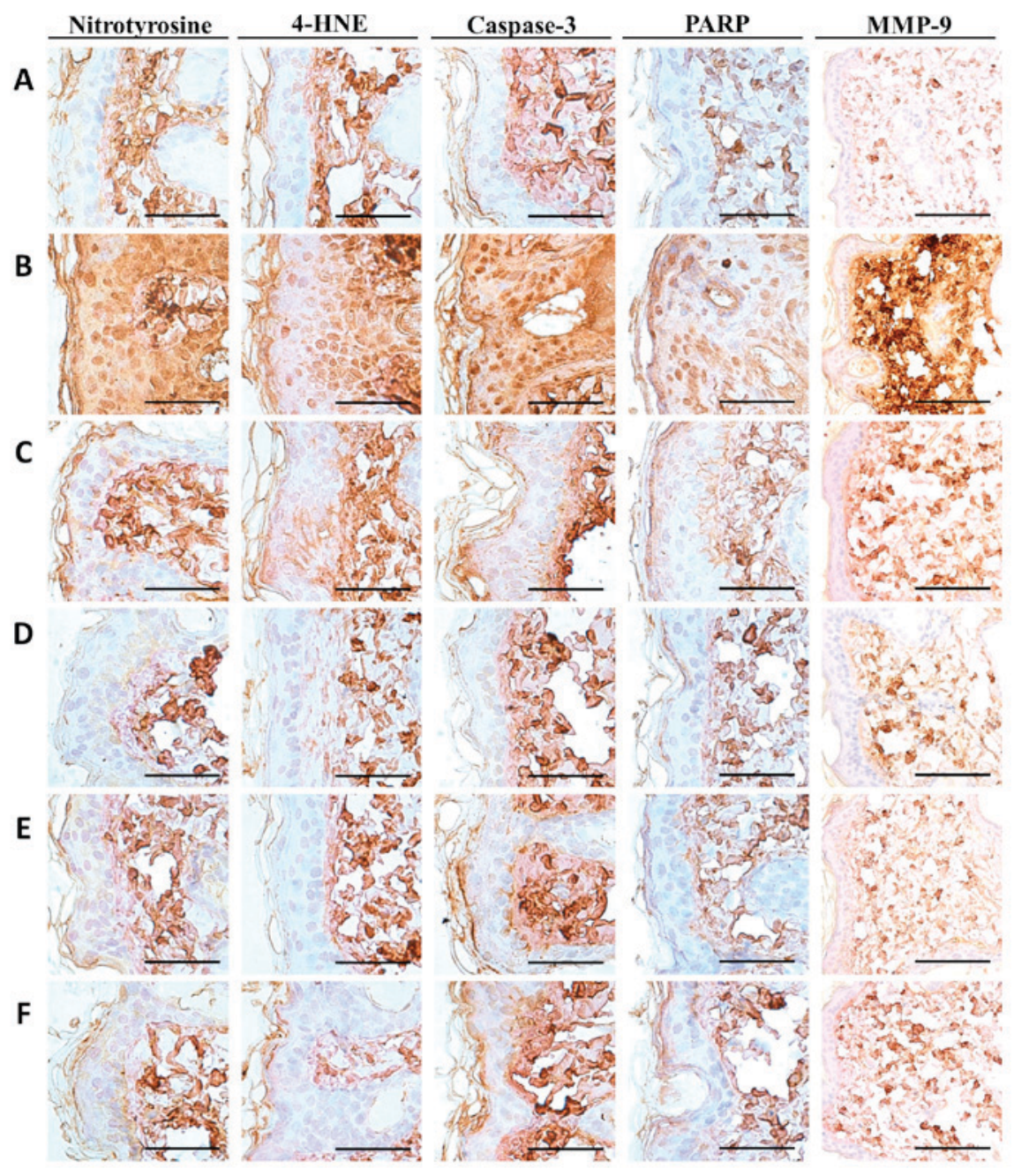

Figure 5. Representative immunohistochemistrical images of dorsal back skin tissues, taken from unexposed intact or UVB-exposed hairless mice. (A) Intact vehicle control; (B) UVB control; (C) UVB-exposed mice treated with $2 \mathrm{ml} / \mathrm{kg}$ PCS mice; (D) UVB-exposed mice treated with $100 \mathrm{mg} / \mathrm{kg}$ PCP; (E) UVB-exposed mice treated with $200 \mathrm{mg} / \mathrm{kg}$ PCP; (F) UVB-exposed mice treated with $400 \mathrm{mg} / \mathrm{kg}$ PCP. All avidin-biotin complex immunostaining. Scale bars $=50 \mu \mathrm{m}$. UVB, ultraviolet B; 4-HNE, 4-hydroxynonenal; PARP, cleaved poly(ADP-ribose) polymerase; MMP-9, matrix metalloproteinase 9; PCP, dried pomegranate juice concentrated powder; PCS, pomegranate juice concentrated solution. 
myeloid white blood cells (52). The results of the current study indicated that PCP decreased UVB-induced MPO activity and dermis inflammatory cell infiltration. Additionally, all three doses of PCP and PCS inhibited the expression of Nox2 mRNA and the production of superoxide anions $(46,53)$. These results support the hypothesis that the antioxidant effect of PCP inhibits the inflammatory processes induced by UVB irradiation.

Following exposure to UVB, human keratinocytes exhibit increased expression of cytokines, including TNF- $\alpha$, IL-1 $\alpha$, IL-1 $\beta$ and IL-6 $(4,6,17)$. IL-1 $\beta$-stimulated neutrophils and other cells upregulate the expression of intercellular adhesion molecules (54). UVB-induced inflammasomes serve an important in regulating the activation of IL-1 $\beta$. Activation of nucleotide-binding oligomerization domain-containing protein (NOD) 1 and NOD2 by UVB leads to the recruitment of the adapter apoptosis-associated speck-like protein, resulting in the activation of pro-caspase-1 into its cleaved form (55). Consequently, caspase-1-depedent cleavage stimulates the activation of IL-1 $\beta$ by pro-IL-1 $\beta$ (56). The results of the current study indicated that IL-1 $\beta$ levels in the PCP- and PCS-treated groups were lower than those in the UVB-exposed group. The inhibition of IL- $1 \beta$ production by PCP is consistent with the inhibition of MPO activity, as IL-1 $\beta$ is chemotactic for neutrophils (57). Inhibition of IL- $1 \beta$ production by PCP may lead to a reduction in neutrophil recruitment and consequently, to a reduction in MPO activity. Furthermore, PCP inhibited gp91phox mRNA expression and the production of superoxide anions; these findings suggest that preventing ROS-mediated IL-1 $\beta$ production may be a mechanism of action of PCP against the effects of UVB irradiation.

IL-10 is a potent anti-inflammatory cytokine that blocks $\mathrm{NF}-\kappa \mathrm{B}$ activity. It regulates inflammatory signaling by reducing levels of UVB radiation-induced pro-inflammatory cytokines (54). Decreases in the levels of UVB-induced IL-10 in the present study were consistent with the results reported by Campanini et al (4). These decreases were reversed following treatment with PCP; thus the protective mechanism of PCP against UVB may be associated with an increase in IL-10 production.

GSH is a sensitive marker of oxidative stress caused by UVB irradiation (58). 4-HNE is a tissue lipid peroxidation marker and is regarded as a potential causal agent in many diseases including chronic inflammation, neurodegenerative disease, adult respiratory distress syndrome, atherogenesis, diabetes and certain types of cancer (59). NT has been identified in the process of tyrosine nitration that is mediated by reactive nitrogen species, including the peroxynitrite anion and nitrogen dioxide, and can be generated by the myeloperoxidase system (60). NT is considered to be an iNOS-dependent marker (61). The results of the current study indicated that PCP inhibits the depletion of endogenous antioxidants. These results suggest that PCP exerts antioxidant activity by maintaining the GSH system and defending against the oxidative stress associated with exposure to UVB.

Previous studies have demonstrated that, in hairless mice, prolonged exposure to UVB causes significant increases in the levels of MMP-1, -9, and -13 (62,63). MMPs are directly responsible for the skin photoaging process; thus, the direct inhibition of MMP activity with a specific inhibitor or the indirect inhibition of MMP by reduction of its expression may be an effective therapeutic method of counteracting photoaging $(9,37)$. In the present study, UVB treatment increased MMP activity and associated abnormal dermal collagen deposition was significantly inhibited following treatment with PCP and PCS. These results indicate that PCP may be effective at preventing photoaging by reducing the expression of MMPs.

UV-mediated mass apoptosis may damage the normal barrier function of the skin and exacerbate skin photoaging (64). It has been demonstrated that UVB-induced apoptosis enhances the expression of caspase-3 and PARP-immunoreactive keratinocytes in the skin epithelium $(7,64)$. The results of the present study determined that increases in epidermal apoptotic markers were dose-dependently inhibited by oral administration of the three doses of PCP and PCS. These observations suggest that PCP may be effective against photoaging by inhibiting epidermal keratinocyte apoptosis $(7,64)$.

Normal human keratin layers contain 10-20\% water, however loss of water content increases wrinkle formation and itching (50). The COL1A1 and COL1A2 genes encode the component COL1, part of the major structural protein type I procollagen (65). Collagen destruction is thought to be responsible for the appearance of aged skin and changes resulting from chronic sun exposure (66). It has been suggested that skin wrinkles and ECM degradation are associated with an increase in the activities of dermal enzymes, including hyaluronidase, collagenase, elastase and MMP-1 (67). Hyaluronan, a major ECM component, serves an important role in maintaining water homeostasis in the skin $(23,30)$ and the synthesis of Has 1, 2, and 3 (30). According to the results of the current study, the groups receiving PCP exhibited increased skin water, COL1 and hyaluronan content. Furthermore, the groups exhibited upregulation of COL1A1 and 2, and of Has 1, 2, and 3 mRNA expression. In particular, levels of COL1A1 and 2, and Has 1, 2, and 3 in mice receiving $100 \mathrm{mg} / \mathrm{kg}$ PCP increased more than those in mice receiving $2 \mathrm{ml} / \mathrm{kg}$ PCS.

There were a few limitations of the present study. SKH-1 hairless mice are wildly used to examine the mechanism and protection of age-related skin changes (40) however, UV-developed wrinkles differ from those in humans as they arise following chronic ultraviolet radiation (UVR) exposure and are associated with epidermal rather than dermal changes $(68,69)$. The UVR-exposed dermis in SKH1 mice exhibits elastic fiber hyperplasia, collagen degradation and elevated glycosaminoglycans, which are associated with alterations in the activity of MMPs. UVR-developed wrinkles in SKH1 mice occur as prominent horizontal creases on the dorsum. In addition, experimental results from the mice model cannot directly be applied to humans due to differences between evaluations of animal target studies and clinically usable evaluations.

Taken together, the results of the current study indicate that protection against UVB-induced photoaging was achieved by treatment with different doses of PCP (100, 200 and $400 \mathrm{mg} / \mathrm{kg}$ ) and $2 \mathrm{ml} / \mathrm{kg}$ PCS. This was due to the active cytoprotective and anti-apoptotic effects, MMP activity inhibition and ECM (COL1 and hyaluronan) synthesis-related moisturizing, anti-inflammatory and anti-oxidative effects of PCP and PCS. PCP may therefore be developed as a functional protective agent against UVB-induced skin photoaging. According 
to the results of the current study, skin aging induced by UVB is most effectively suppressed by treatment with $200 \mathrm{mg} / \mathrm{kg}$ PCP. In humans, the equivalent dose is $1 \mathrm{~g} /$ person for humans. Therefore, the clinical efficacy of $1 \mathrm{~g} /$ person PCP against skin photoaging in humans should be investigated further.

\section{Acknowledgements}

The present study was supported by the National Research Foundation of Korea grant funded by the Korean government (grant no. 2012R1A5A2A42671316). The authors Mr Beom-Rak Choi, Mrs Seung-Hee Kim, Mrs Hae-Yeon Yi and Mrs Hye-Rim Park are employees at Health-Love Co., Ltd.

\section{References}

1. Chaquour B, Seité S, Coutant K, Fourtanier A, Borel JP and Bellon G: Chronic UVB- and all-trans retinoic-acid-induced qualitative and quantitative changes in hairless mouse skin. J Photochem Photobiol B 28: 125-135, 1995.

2. Fisher GJ, Kang S, Varani J, Bata-Csorgo Z, Wan Y, Datta S and Voorhees JJ: Mechanisms of photoaging and chronological skin aging. Arch Dermatol 138: 1462-1470, 2002.

3. Gilchrest BA: A review of skin ageing and its medical therapy. $\mathrm{Br}$ J Dermatol 135: 867-875, 1996.

4. Campanini MZ, Pinho-Ribeiro FA, Ivan AL, Ferreira VS, Vilela FM, Vicentini FT, Martinez RM, Zarpelon AC, Fonseca MJ, Faria TJ, et al: Efficacy of topical formulations containing Pimenta pseudocaryophyllus extract against UVB-induced oxidative stress and inflammation in hairless mice. J Photochem Photobiol B 127: 153-160, 2013.

5. Ono R, Fukunaga A, Masaki T, Yu X, Yodoi J and Nishigori C: Suppressive effect of administration of recombinant human thioredoxin on cutaneous inflammation caused by UV. Bioengineered 4: 254-257, 2013.

6. Duncan FJ, Martin JR, Wulff BC, Stoner GD, Tober KL, Oberyszyn TM, Kusewitt DF and Van Buskirk AM: Topical treatment with black raspberry extract reduces cutaneous UVB-induced carcinogenesis and inflammation. Cancer Prev Res (Phila) 2: 665-672, 2009.

7. Hasegawa T, Shimada S, Ishida $\mathrm{H}$ and Nakashima M: Chafuroside $\mathrm{B}$, an Oolong tea polyphenol, ameliorates UVB-induced DNA damage and generation of photo-immunosuppression related mediators in human keratinocytes. PLoS One 8: e77308, 2013.

8. Lei X, Liu B, Han W, Ming M and He YY: UVB-Induced p21 degradation promotes apoptosis of human keratinocytes Photochem Photobiol Sci 9: 1640-1648, 2010.

9. Jin XJ, Kim EJ, Oh IK, Kim YK, Park CH and Chung JH: Prevention of UV-induced skin damages by 11, 14, 17-eicosatrienoic acid in hairless mice in vivo. J Korean Med Sci 25: 930-937, 2010

10. Kang TH, Park HM, Kim YB, Kim H, Kim N, Do JH, Kang C, Cho Y and Kim SY: Effects of red ginseng extract on UVB irradiation-induced skin aging in hairless mice. J Ethnopharmacol 123: 446-451, 2009

11. Kawada C, Kimura M, Masuda Y and Nomura Y: Oral administration of hyaluronan prevents skin dryness and epidermal thickening in ultraviolet irradiated hairless mice. J Photochem Photobiol B 153: 215-221, 2015.

12. Bae JY, Choi JS, Choi YJ, Shin SY, Kang SW, Han SJ and Kang YH: (-)Epigallocatechin gallate hampers collagen destruction and collagenase activation in ultraviolet-B-irradiated human dermal fibroblasts: Involvement of mitogen-activated protein kinase. Food Chem Toxicol 46: 1298-1307, 2008.

13. Valko M, Leibfritz D, Moncol J, Cronin MT, Mazur M and Telser J: Free radicals and antioxidants in normal physiological functions and human disease. Int J Biochem Cell Biol 39: 44-84, 2007.

14. Casagrande R, Georgetti SR, Verri WA Jr, Dorta DJ, dos Santos AC and Fonseca MJ: Protective effect of topical formulations containing quercetin against UVB-induced oxidative stress in hairless mice. J Photochem Photobiol B 84: 21-27, 2006.
15. Hanada K, Sawamura D, Tamai K, Hashimoto I and Kobayashi S: Photoprotective effect of esterified glutathione against ultraviolet B-induced sunburn cell formation in the hairless mice. J Invest Dermatol 108: 727-730, 1997.

16. Obermüller-Jevic UC, Schlegel B, Flaccus A and Biesalski HK: The effect of beta-carotene on the expression of interleukin-6 and heme oxygenase-1 in UV-irradiated human skin fibroblasts in vitro. FEBS Lett 509: 186-190, 2001

17. El-Abaseri TB, Hammiller B, Repertinger SK and Hansen LA: The epidermal growth factor receptor increases cytokine production and cutaneous inflammation in response to ultraviolet irradiation. ISRN Dermatol 2013: 848705, 2013.

18. Kvietys PR and Granger DN: Role of reactive oxygen and nitrogen species in the vascular responses to inflammation. Free Radic Biol Med 52: 556-592, 2012.

19. Verri WA Jr, Vicentini FTMC, Baracat MM, Georgetti SR, Cardoso RDR, Cunha TM, Ferreira SH, Cunha FQ, Fonesca MJV and Casagrande R: Flavonoids as anti-inflammatory and analgesic drugs: Mechanisms of action and perspectives in the development of pharmaceutical forms. In: Studies in Natural Products Chemistry: Bioactive Natural Products. (Part P). Atta-Ur-Rahman (ed). Elsevier, Amsterdam, pp297-322, 2012.

20. Gil MI, Tomás-Barberán FA, Hess-Pierce B, Holcroft DM and Kader AA: Antioxidant activity of pomegranate juice and its relationship with phenolic composition and processing. J Agric Food Chem 48: 4581-4589, 2000.

21. Noda Y, Kaneyuki T, Mori A and Packer L: Antioxidant activities of pomegranate fruit extract and its anthocyanidins: Delphinidin, cyanidin, and pelargonidin. J Agric Food Chem 50: 166-171, 2002.

22. Kim ND, Mehta R, Yu W, Neeman I, Livney T, Amichay A, Poirier D, Nicholls P, Kirby A, Jiang W, et al: Chemopreventive and adjuvant therapeutic potential of pomegranate (Punica granatum) for human breast cancer. Breast Cancer Res Treat 71: 203-217, 2002.

23. Kang SJ, Choi BR, Kim SH, Yi HY, Park HR, Park SJ, Song CH, Park JH, Lee YJ and Kwang S: Inhibitory effects of pomegranate concentrated solution on the activities of hyaluronidase, tyrosinase, and metalloproteinase. J Cosmet Sci 66: 145-159, 2015.

24. Kang SJ, Choi BR, Kim SH, Yi HY, Park HR, Song CY, Park SJ, $\mathrm{Ku}$ SK and Lee YJ: Effect of pomegranate concentration solution on photoaging. J Soc Preventive Korean Med 19: 109-116, 2015.

25. Kang SJ, Choi BR, Lee EK, Kim SH, Yi HY, Park HR, Song CH, Lee YJ and Ku SK: Inhibitory effect of dried pomegranate concentration powder on melanogenesis in B16F10 melanoma cells; involvement of p38 and PKA signaling pathways. Int J Mol Sci 16: 24219-24242, 2015.

26. Committee for the Update of the Guide for the Care and Use of Laboratory Animals, Institute for Laboratory Animal Resources, Division on Earth and Life Studies and National Research Council of the National Academies: Guide for the Care and Use of Laboratory Animals. The National Academies Press, Washington, DC, 2011.

27. Jung SK, Lee KW, Kim HY, Oh MH, Byun S, Lim SH, Heo YS, Kang NJ, Bode AM, Dong Z and Lee HJ: Myricetin suppresses UVB-induced wrinkle formation and MMP-9 expression by inhibiting Raf. Biochem Pharmacol 79: 1455-1461, 2010.

28. Kim KH, Park SJ, Lee JE, Lee YJ, Song CH, Choi SH, Ku SK and Kang SJ: Anti-skin-aging benefits of exopolymers from Aureobasidium pullulans SM2001. J Cosmet Sci 65: 285-298, 2014.

29. Kim YH, Chung CB, Kim JG, Ko KI, Park SH, Kim JH, Eom SY, Kim YS, Hwang YI and Kim KH: Anti-wrinkle activity of ziyuglycoside I isolated from a Sanguisorba officinalis root extract and its application as a cosmeceutical ingredient. Biosci Biotechnol Biochem 72: 303-311, 2008.

30. Yamane T, Nakagami G, Yoshino S, Muramatsu A, Matsui S, Oishi Y, Kanazawa T, Minematsu T and Sanada H: Hydrocellular foam dressing promotes wound healing along with increases in hyaluronan synthase 3 and PPAR $\alpha$ gene expression in epidermis. PLoS One 8: e73988, 2013.

31. Lowry OH, Rosebrough NJ, Farr AL and Randall RJ: Protein measurement with the Folin phenol reagent. J Biol Chem 193: 265-275, 1951.

32. Botelho MA, Rao VS, Carvalho CB, Bezerra-Filho JG, Fonseca SG, Vale ML, Montenegro D, Cunha F, Ribeiro RA and Brito GA: Lippia sidoides and Myracrodruon urundeuva gel prevents alveolar bone resorption in experimental periodontitis in rats. J Ethnopharmacol 113: 471-478, 2007. 
33. Jamall IS and Smith JC: Effects of cadmium on glutathione peroxidase, superoxide dismutase, and lipid peroxidation in the rat heart: A possible mechanism of cadmium cardiotoxicity. Toxicol Appl Pharmacol 80: 33-42, 1985.

34. Barbosa DS, Cecchini R, El Kadri MZ, Rodríguez MA, Burini RC and Dichi I: Decreased oxidative stress in patients with ulcerative colitis supplemented with fish oil omega-3 fatty acids. Nutrition 19: 837-842, 2003.

35. Harrigan TJ, Abdullaev IF, Jourd'heuil D and Mongin AA: Activation of microglia with zymosan promotes excitatory amino acid release via volume-regulated anion channels: The role of NADPH oxidases. J Neurochem 106: 2449-2462, 2008.

36. Livak KJ and Schmittgen TD: Analysis of relative gene expression data using real-time quantitative PCR and the 2(-Delta Delta C(T)) method. Methods 25: 402-408, 2001.

37. Kim KH, Park SJ, Lee YJ, Lee JE, Song CH, Choi SH, Ku SK and Kang SJ: Inhibition of UVB-induced skin damage by exopolymers from Aureobasidium pullulans SM-2001 in hairless mice. Basic Clin Pharmacol Toxicol 116: 73-86, 2015.

38. Burns T, Breathnach S, Cox N and Griffiths C: Rook's Textbook of Dermatology. Blackwell Science, Massachusetts, MA, 2004.

39. Xu Y, Shao Y, Voorhees JJ and Fisher GJ: Oxidative inhibition of receptor-type protein-tyrosine phosphatase kappa by ultraviolet irradiation activates epidermal growth factor receptor in human keratinocytes. J Biol Chem 281: 27389-27397, 2006.

40. Kligman LH: The hairless mouse model for photoaging. Clin Dermatol 14: 183-195, 1996.

41. Afaq F, Khan N, Syed DN and Mukhtar H: Oral feeding of pomegranate fruit extract inhibits early biomarkers of UVB radiation-induced carcinogenesis in SKH-1 hairless mouse epidermis. Photochem Photobiol 86: 1318-1326, 2010.

42. Bosch R, Philips N, Suárez-Pérez JA, Juarranz A, Devmurari A Chalensouk-Khaosaat J and González S: Mechanisms of photoaging and cutaneous photocarcinogenesis, and photoprotective strategies with phytochemicals. Antioxidants (Basel) 4: 248-268, 2015.

43. Shaygannia E, Bahmani M,Zamanzad B and Rafieian-Kopaei M: A review study on Punica granatum L. J Evid Based Complementary Altern Med 21: 221-227, 2016.

44. Schubert SY, Lansky EP and Neeman I: Antioxidant and eicosanoid enzyme inhibition properties of pomegranate seed oil and fermented juice flavonoids. J Ethnopharmacol 66: 11-17, 1999.

45. Aviram M, Dornfeld L, Rosenblat M, Volkova N, Kaplan M, Coleman R, Hayek T, Presser D and Fuhrman B: Pomegranate juice consumption reduces oxidative stress, atherogenic modifications to LDL, and platelet aggregation: Studies in humans and in atherosclerotic apolipoprotein E-deficient mice. Am J Clin Nutr 71: 1062-1076, 2000

46. Witko-Sarsat V, Rieu P, Descamps-Latscha B, Lesavre P and Halbwachs-Mecarelli L: Neutrophils: Molecules, functions and pathophysiological aspects. Lab Invest 80: 617-653, 2000.

47. Mittal M, Siddiqui MR, Tran K, Reddy SP and Malik AB Reactive oxygen species in inflammation and tissue injury. Antioxid Redox Signal 20: 1126-1167, 2014.

48. Zimmerman BJ, Grisham MB and Granger DN: Role of oxidants in ischemia/reperfusion-induced granulocyte infiltration. Am J Physiol 258: G185-G190, 1990.

49. Sullivan GW, Sarembock IJ and Linden J: The role of inflammation in vascular diseases. J Leukoc Biol 67: 591-602, 2000.

50. Kim HJ, Kim CH, Ryu JH, Joo JH, Lee SN, Kim MJ, Lee JG, Bae YS and Yoon JH: Crosstalk between platelet-derived growth factor-induced Nox4 activation and MUC8 gene overexpression in human airway epithelial cells. Free Radic Biol Med 50: 1039-1052, 2011.

51. O'Leary DP, Bhatt L, Woolley JF, Gough DR, Wang JH, Cotter TG and Redmond HP: TLR-4 signalling accelerates colon cancer cell adhesion via NF- $\mathrm{B}$ mediated transcriptional up-regulation of Nox-1. PLoS One 7: e44176, 2012.
52. Krause KH: Tissue distribution and putative physiological function of NOX family NADPH oxidases. Jpn J Infect Dis 57: S28-S29, 2004

53. Hattori H, Subramanian KK, Sakai J and Luo HR: Reactive oxygen species as signaling molecules in neutrophil chemotaxis. Commun Integr Biol 3: 278-281, 2010.

54. Weiss E, Mamelak AJ, La Morgia S, Wang B, Feliciani C, Tulli A and Sauder DN: The role of interleukin 10 in the pathogenesis and potential treatment of skin diseases. J Am Acad Dermatol 50: 657-675; quiz 676-658, 2004

55. Benko S, Tozser J, Miklossy G, Varga A, Kadas J, Csutak A, Berta A and Rajnavolgyi E: Constitutive and UV-B modulated transcription of Nod-like receptors and their functional partners in human corneal epithelial cells. Mol Vis 14: 1575-1583, 2008.

56. Takeishi A, Kuranaga E and Miura M: Sensing and reacting to dangers by caspases: Caspase activation via inflammasomes. Drug Discov Ther 2: 14-23, 2008.

57. Bellosta S, Dell'Agli M, Canavesi M, Mitro N, Monetti M, Crestani M, Verotta L, Fuzzati N, Bernini F and Bosisio E: Inhibition of metalloproteinase-9 activity and gene expression by polyphenolic compounds isolated from the bark of Tristaniopsis calobuxus (Myrtaceae). Cell Mol Life Sci 60: 1440-1448, 2003.

58. de Gruijl FR: Skin cancer and solar UV radiation. Eur J Cancer 35: 2003-2009, 1999.

59. Smathers RL, Galligan JJ, Stewart BJ and Petersen DR: Overview of lipid peroxidation products and hepatic protein modification in alcoholic liver disease. Chem Biol Interact 192: 107-112, 2011.

60. Kettle AJ, van Dalen CJ and Winterbourn CC: Peroxynitrite and myeloperoxidase leave the same footprint in protein nitration. Redox Rep 3: 257-258, 1997.

61. Pacher P, Beckman JS and Liaudet L: Nitric oxide and peroxynitrite in health and disease. Physiol Rev 87: 315-424, 2007.

62. Inomata S, Matsunaga Y, Amano S, Takada K, Kobayashi K, Tsunenaga M, Nishiyama T, Kohno Y and Fukuda M: Possible involvement of gelatinases in basement membrane damage and wrinkle formation in chronically ultraviolet B-exposed hairless mouse. J Invest Dermatol 120: 128-134, 2003.

63. Kim HH, Lee MJ, Lee SR, Kim KH, Cho KH, Eun HC and Chung JH: Augmentation of UV-induced skin wrinkling by infrared irradiation in hairless mice. Mech Ageing Dev 126: 1170-1177, 2005.

64. El-Mahdy MA, Zhu Q, Wang QE, Wani G, Patnaik S, Zhao Q, Arafa el-S, Barakat B, Mir SN and Wani AA: Naringenin protects $\mathrm{HaCaT}$ human keratinocytes against UVB-induced apoptosis and enhances the removal of cyclobutane pyrimidine dimers from the genome. Photochem Photobiol 84: 307-316, 2008.

65. Wallis GA, Sykes B, Byers PH, Mathew CG, Viljoen D and Beighton P: Osteogenesis imperfecta type III: Mutations in the type I collagen structural genes, COL1A1 and COL1A2, are not necessarily responsible. J Med Genet 30: 492-496, 1993.

66. Liao PL, Li CH, Chang CY, Lu SR, Lin CH, Tse LS and Cheng YW: Anti-ageing effects of alpha-naphthoflavone on normal and UVB-irradiated human skin fibroblasts. Exp Dermatol 21: 546-548, 2012.

67. Maity N, Nema NK, Abedy MK, Sarkar BK and Mukherjee PK: Exploring Tagetes erecta Linn flower for the elastase, hyaluronidase and MMP-1 inhibitory activity. J Ethnopharmacol 137: 1300-1305, 2011

68. Kambayashi H, Yamashita M, Odake Y, Takada K, Funasaka Y and Ichihashi M: Epidermal changes caused by chronic low-dose UV irradiation induce wrinkle formation in hairless mouse. J Dermatol Sci 27 (Suppl 1): S19-S25, 2001.

69. Moloney SJ, Edmonds SH, Giddens LD and Learn DB: The hairless mouse model of photoaging: Evaluation of the relationship between dermal elastin, collagen, skin thickness and wrinkles. Photochem Photobiol 56: 505-511, 1992. 